INTER NATIONAL MONETARY FUND

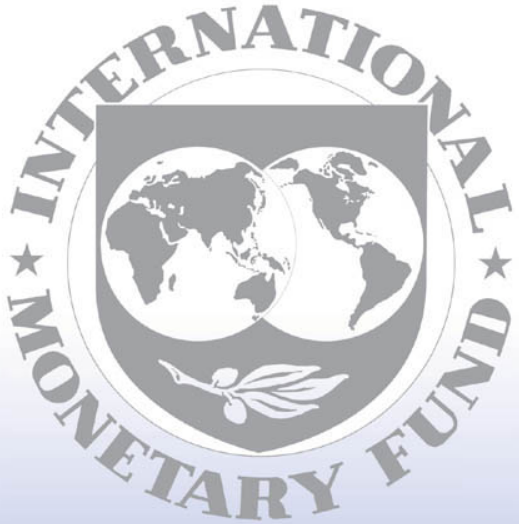

Staff

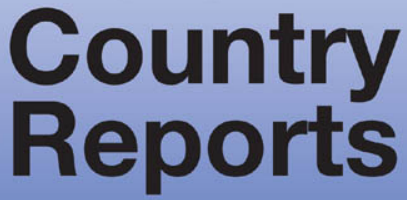




\section{United Arab Emirates: 2005 Article IV Consultation-Staff Report; Public Information Notice on the Executive Board Discussion; and Statement by the Executive Director for the United Arab Emirates}

Under Article IV of the IMF's Articles of Agreement, the IMF holds bilateral discussions with members, usually every year. In the context of the 2005 Article IV consultation with the United Arab Emirates, the following documents have been released and are included in this package:

- the staff report for the 2005 Article IV consultation, prepared by a staff team of the IMF, following discussions that ended on July 1, 2005, with the officials of the United Arab Emirates on economic developments and policies. Based on information available at the time of these discussions, the staff report was completed on June 8, 2005. The views expressed in the staff report are those of the staff team and do not necessarily reflect the views of the Executive Board of the IMF.

- a Public Information Notice (PIN) summarizing the views of the Executive Board as expressed during its July 1, 2005 discussion of the staff report that concluded the Article IV consultation.

- $\quad$ a statement by the Executive Director for the United Arab Emirates.

The document listed below has been or will be separately released.

Selected Issues Paper and Statistical Appendix

The policy of publication of staff reports and other documents allows for the deletion of market-sensitive information.

To assist the IMF in evaluating the publication policy, reader comments are invited and may be sent by e-mail to publicationpolicy@imf.org.

Copies of this report are available to the public from

International Monetary Fund $\bullet$ Publication Services

$70019^{\text {th }}$ Street, N.W. $\bullet$ Washington, D.C. 20431

Telephone: (202) 623-7430 • Telefax: (202) 623-7201

E-mail: publications@imf.org・Internet: http://www.imf.org

Price: $\$ 15.00$ a copy

International Monetary Fund

Washington, D.C. 
This page intentionally left blank

CInternational Monetary Fund. Not for Redistribution 


\title{
INTERNATIONAL MONETARY FUND
}

\author{
UNITED ARAB EMIRATES \\ Staff Report for the 2005 Article IV Consultation
}

\author{
Prepared by the Staff Representatives for the 2005 Consultation with \\ the United Arab Emirates
}

Approved by Julian Berengaut and Carlos Muñiz

June 7, 2005

The consultation discussions were held in Abu Dhabi, Dubai, and Sharjah from March 16 through 30, 2005. The mission team met with the Minister of State for Finance and Industry, the Governor of the Central Bank, Under Secretaries of the Ministries of Finance and Industry, Economy and Planning, Labor and Social Affairs, as well as senior officials of the Federal government and the three largest Emirates-Abu Dhabi, Dubai, and Sharjah. Meetings were also held with representatives of the private sector, commercial banks, stock exchanges, and chief executives of several public enterprises. The staff team comprised Messrs. Elhage (head), Erbas, Floerkemeier, Goswami, Ms. Farahbaksh (all MCD), and Mr. Crowley (MFD). The mission was part of the pilot project to test implementation of the draft MFD-PDR guidance note on financial sector surveillance in Article IV consultations.

In concluding the last consultation on May 28, 2004, Executive Directors commended the U.A.E. for pursuing prudent macroeconomic policies, a sound management of oil resources, and an outward-oriented development strategy. All of these have resulted in low inflation and high growth, as well as sizable fiscal and external current account surpluses, and the accumulation of foreign assets. Further, they noted that sound policies supported by structural reforms have enhanced the role of the private sector, contributed to growth of the nonhydrocarbon sector and diversification of the economy, and strengthened the economy's resilience to external shocks.

To sustain U.A.E.'s strong economic performance, Directors saw scope for further strengthening fiscal policy, the financial sector, and the economic structure. They called on the authorities to improve the structure of the budget over the medium term. Directors encouraged the authorities to set up a transparent investment regime, and to improve ownership rights for foreigners. They commended the authorities for the provision of data on the government's foreign assets. However, they noted that improvements in the U.A.E.'s economic statistics, with regard to data quality, coverage, periodicity, timeliness, and consistency, depend on increased coordination between the Federal and Emirates' authorities and the training of staff.

The United Arab Emirates has accepted the obligations of Article VIII, Sections 2, 3, and 4. It has also accepted the Fourth Amendment of the Fund's Articles of Agreement.

Appendices I and II provide information on relations with the Fund and the World Bank Group, respectively. Statistical issues are discussed in Appendix III. Financial sector developments, including the status of 2001 FSAP recommendations, are discussed in Appendix IV. Appendix V presents the background section of the Press Information Notice (PIN). 
Executive Summary

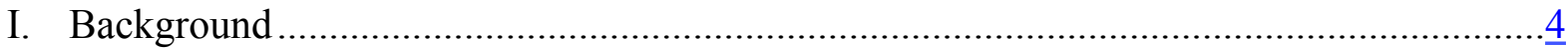

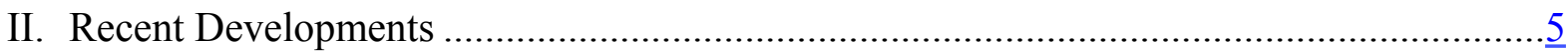

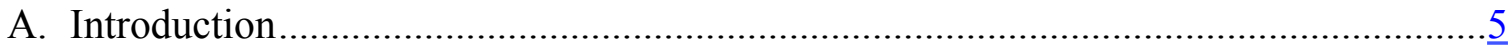

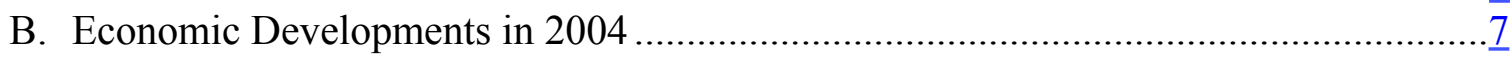

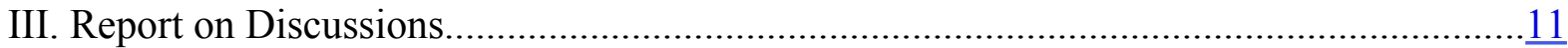

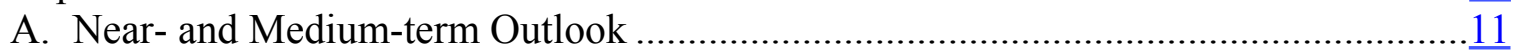

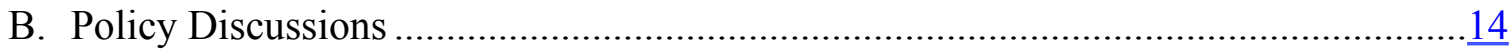

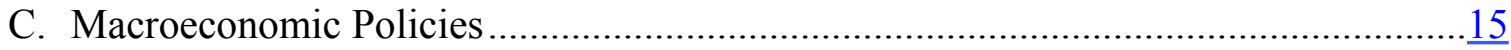

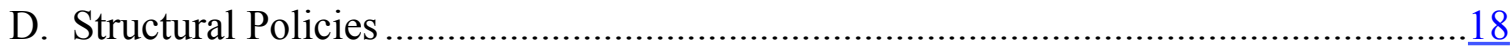

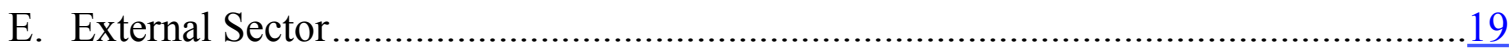

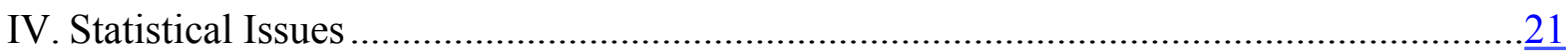

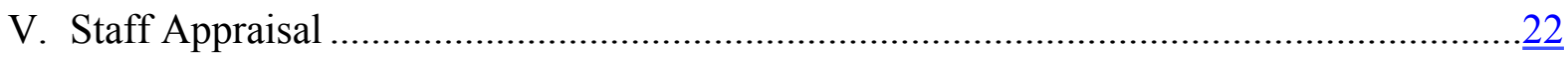

Text Boxes

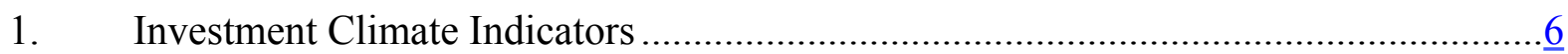

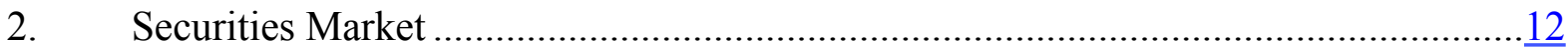

3. Recent Developments in the Oil Market and Prospects for the U.A.E. Hydrocarbon Sector ............................................................................14

4. Labor Market Developments and Prospects...........................................................

Tables

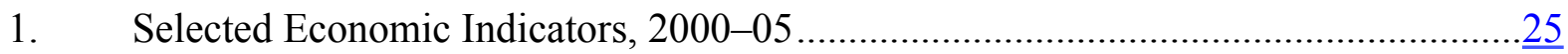

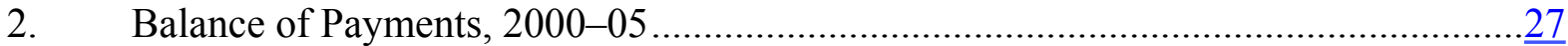

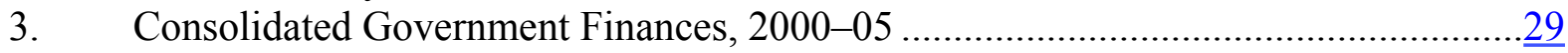

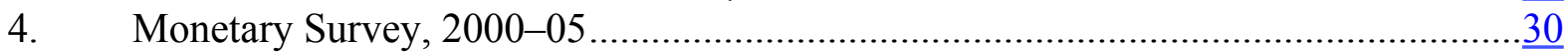

5. Selected Indicators of External Vulnerability, 2000-04 ..........................................

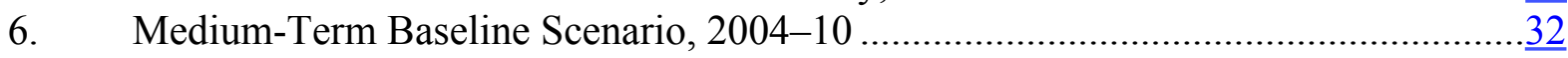

Appendices

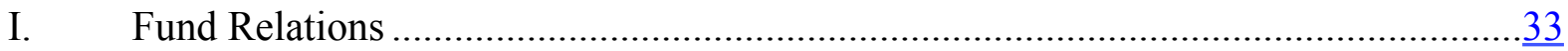

II. Relations with the World Bank Group.............................................................

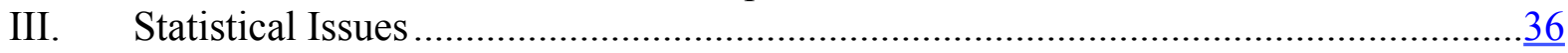

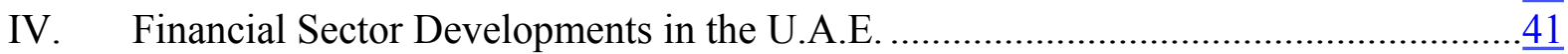

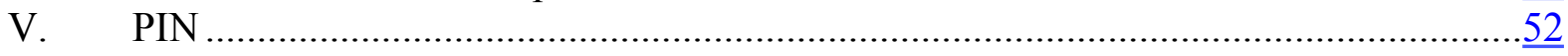




\section{EXECUTIVE SUMMARY}

\section{Background}

In 2004, reflecting sharply higher oil prices and increased oil production, strong investor confidence, and a significant increase in foreign direct investment (FDI), economic growth in the U.A.E. is estimated to have been very strong. Real nonhydrocarbon GDP growth is estimated at 10 percent. Both the external current account and consolidated fiscal balances are estimated to have recorded large surpluses, 12 percent and 18.3 percent of GDP, respectively. The nonhydrocarbon deficit also narrowed. Prices in the real estate and the stock markets have soared aided by stronger economic fundamentals and investor optimism. Inflation as measured by the Consumer Price Index increased by 4.6 percent.

The banking sector in the U.A.E remains strong, bolstered by effective supervision. Overall, the capitalassets ratio declined slightly to just under 17 percent and the ratio of net nonperforming loans to total loans remained below 4 percent. Major steps have been taken to put in place a strong legal framework to prevent money laundering and financing of terrorist activities. The Dubai International Financial Center (DIFC) began operations in September 2004 and significant progress has been made with respect to the regulatory framework governing the DIFC which has been benchmarked to best international practices.

\section{Medium-term Context}

On the basis of current expectations for oil prices and current policy stance, the medium-term outlook remains favorable. However, pressures may build for an increase in expenditures to address the emerging unemployment and potential unfunded pension liabilities. Also, there are some risks in the system that warrant close monitoring, in particular, soaring asset prices and accelerating inflationary pressure.

\section{Staff Appraisal}

An outward-oriented development strategy and prudent financial policies have resulted in impressive economic growth over the years. Economic diversification has advanced rapidly, underpinned by an increasing role of the private sector. Openness, favorable business environment, and a good record in macroeconomic management have laid the foundation for further economic and social progress in the period ahead.

There is a need for full rationalization and consolidation of the regulatory oversight related to the capital markets and nonfinancial bank intermediaries. Also, regulations pertaining to investment and finance companies will need to be strengthened, and gaps need to be addressed in order to safeguard investor interests. Employment opportunities for nationals will need to be created through long-term structural policies in the areas of education, training, wage policy, and labor legislation.

The structure of the budget needs to be strengthened. On the expenditure side, government employment needs to be contained and rewards increasingly based on productivity. The revenue base could be broadened by introducing a VAT system at the Federal level and the Emirates could consider introducing a property tax. Financial polices might need to be tightened to contain inflationary pressure.

Fiscal transparency needs to be improved and there is an urgent need to address the numerous structural weaknesses with respect to data quality, coverage, periodicity, timeliness, and inter-sectoral consistency. 


\section{BACKGROUND}

1. The U.A.E. is a confederation of seven Emirates ${ }^{1}$ each operating under considerable autonomy. This arrangement leaves a great deal of independence to the individual Emirates in pursuing an economic strategy based on their respective comparative advantages. Abu Dhabi, which accounts for about 95 percent of the U.A.E.'s oil and natural gas resources, has pursued prudent economic policies and continues to develop its hydrocarbon capacity along with saving considerable financial assets. Dubai is emerging as a model for economic diversification of the nonhydrocarbon sector and vying for being a leading business hub in the global marketplace. These two Emirates account for about 85 percent of the country's total GDP. The other Emirates rely on a mix of trade and light manufacturing, and they depend on financial support from the Federal government and Abu Dhabi and Dubai governments.

\section{The U.A.E. has relatively small national working age population-albeit} rapidly rising and reliant on government jobs - and is, therefore, highly dependent on a large expatriate labor force. In 2004, nationals in the U.A.E. accounted for about 9 percent and 21 percent of the total labor force and population, respectively.

\section{In recent years, the Fund's policy advice has encouraged the authorities} to strengthen fiscal policy and address data deficiencies across sectors. Modernization of the financial sector's legal framework and improvement in securities and insurance supervision and regulation have also been recommended. The decentralized policymaking process and the complexity of the U.A.E.'s political structure have made it difficult for the authorities to implement the Fund's policy recommendations in the fiscal area. In contrast, important progress has been made in financial sector reforms, as the Central Bank of the U.A.E. (CBU) has unified authority over most institutions in the sector.

4. The U.A.E.'s economic statistics suffer from numerous structural weaknesses with respect to data quality, coverage, periodicity, timeliness, and inter-sectoral consistency (discussed in Appendix III), all of which have hampered the staff's ability to conduct economic analysis and effective surveillance. Increased coordination between Federal and Emirate authorities, adequate resources allocated to data collection and management, and training of staff are necessary conditions for further progress on data issues.

\footnotetext{
${ }^{1}$ The seven Emirates are Abu Dhabi, Dubai, Sharjah, Ajman, Ras al-Khaimah, Umm al-Qaiwain, and Fujairah.
} 


\section{RECENT DEVELOPMENTS}

\section{A. Introduction}

5. Reflecting sharply higher oil prices and increased oil production, strong investor confidence, and a significant increase in FDI, economic growth in the U.A.E. is estimated to have been very strong in 2004. The depreciation of the U.A.E. dirham (AED) in real effective terms and the strong economic growth in the U.A.E.'s export markets helped drive a faster growth in manufactured exports.

6. The pace of liberalization gained momentum, in particular in Dubai and to a lesser extent in the other Emirates. Dubai's policy of extending foreign ownership of land and properties for real estate developments has resulted in a construction boom and a significant increase in FDI in this sector. Sharjah has established a number of industrial free zones while Abu Dhabi has embraced utility privatization, with the objective of privatizing its entire water and electricity sector by 2006. Consideration is being given in Abu Dhabi to follow Dubai's example of relaxing government control over the real estate market.

7. Diversification and competitiveness of the economy continue to be achieved by maintaining a business-friendly environment with good infrastructure. Access to expatriate workers at internationally competitive wages has also contributed to the efficiency of the economy. These factors have made the U.A.E. an attractive place to invest in, particularly in the free zones, for companies seeking to serve the growing markets of the Middle East, North Africa, India, and Pakistan (Box 1).

8. In 2004, financial market developments in the U.A.E. were dominated by further strengthening of banks' balance sheets and significant increases in asset prices. The stronger overall financial position and improved fundamentals of the economy prompted a one-notch upgrade of the U.A.E.'s sovereign rating, to A1 by Moody’s in October 2004. 


\section{Box 1. U.A.E.: Investment Climate Indicators}

Growth Competitiveness Index

\begin{tabular}{lcc}
\hline & Rank & Score \\
\hline U.A.E. & 16 & 5.21 \\
Singapore & 7 & 5.56 \\
Hong Kong & 21 & 5.06 \\
Chile & 22 & 5.01 \\
& & \\
Bahrain & 28 & 4.91 \\
Tunisia & 42 & 4.51 \\
Morocco & 56 & 4.06 \\
\hline
\end{tabular}

Source: World Economic Forum

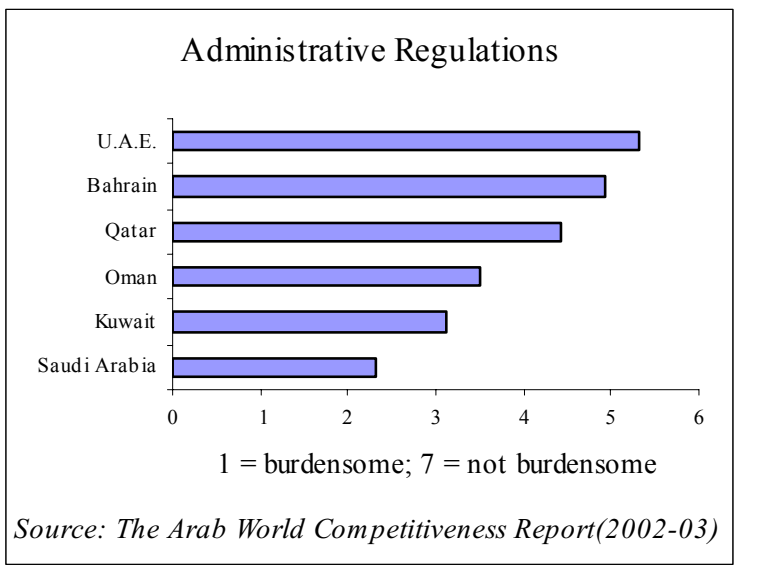

The U.A.E., led by Dubai, has strived to provide a stable economic and efficiently functioning business environment. The perception of the global business community has been relatively favorable in terms of economic, financial and investment risks. The Growth Competitive Index for 2004-a composite of macroeconomic environment, state of public institutions, and technology readiness - ranks the U.A.E. $16^{\text {th }}$ in the world with a high score of 5.21 and at the top of the list among the Gulf Cooperation Council (GCC) countries. Euro money has classified the U.A.E. as the safest Arab country for investment.

The U.A.E. fares well in most of the priority areas of investment climate. Based on the Executive Opinion Survey in the Arab World (The Arab World Competitiveness Report 2002-03), the U.A.E. ranks the highest in having the least burdensome administrative regulations when compared to its GCC peers. When benchmarked on global standards, the U.A.E. ranks fourth, following Singapore, Hong Kong and Iceland.

The U.A.E. ranks 25 th on a global scale in Information and Communication Technology (ICT). The government has been very proactive in prioritizing ICT as a basis for improving efficiency and delivery. Also, at the firm level, technological absorption has been among the most advanced, while public access to internet has grown to have one of the highest intensity.

Based on the World Bank's survey for Doing Business, the cost to create collateral (taxes, fees and duties associated with creating and registering collateral) as a percent of income per capita and the rigidity of employment are low when compared to its regional average. Bank financing is relatively accessible although capital markets are still in the incipient stages. However, due to low disclosure standards, protecting investors' contracts still need reform. Also, the number of procedures and the cost of enforcing contracts are burdensome, lagging global benchmarks such as OECD.

Doing Business - Snapshot of Busienss Environment

\begin{tabular}{lccc}
\hline \multicolumn{1}{c}{ Indicator } & U.A.E. & Regional Average & OECD Average \\
\hline Rigidity of employment index (Avg. hours, hiring \& firing) 1/ & 33.0 & 38.7 & 34.4 \\
Cost to create collateral (percent of income per capita) & 9.4 & 18.5 & 5.2 \\
Protecting investors & & & 5.6 \\
$\quad$ Disclosure Index (ownership, audit, financial information) 2/ & 2.0 & 2.6 & 19.0 \\
Enforcing Contract & & & 10.8 \\
$\quad$ Number of procedures & 53.0 & 38.0 & \\
$\quad$ Cost (percent of debt) & 16.0 & 17.9 & \\
\hline 1/ Lower score = less rigid & & & \\
2/ Higher score = more disclosure of information & & & \\
Source: The World Bank &
\end{tabular}




\section{B. Economic Developments in 2004}

\section{Real sector}

9. Major revisions have been made to GDP data for 2002 and 2003, indicating a stronger overall growth than previously estimated, as well as significant changes in the contribution of the different sectors to overall economic activity. ${ }^{2}$ On average, the real non-oil GDP growth rate for 2002-03 was revised upward by 4.2 percentage points to 9.3 percent.

\section{Preliminary data for $\mathbf{2 0 0 4}$ indicate} that the real nonhydrocarbon GDP grew at 10 percent, while hydrocarbon production

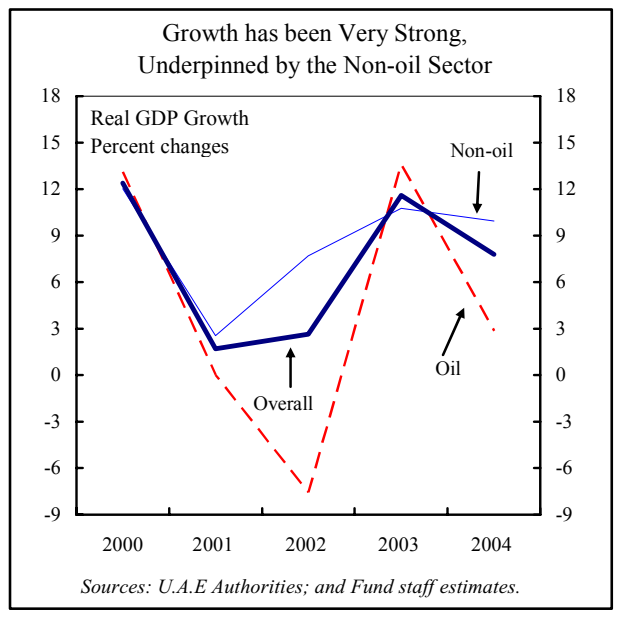
rose by 3 percent (Table 1). Growth was broad-based with most sub-sectors growing at historically high rates, with manufacturing leading the way, followed by services and construction.

\section{The strength of the economy and} higher import prices have, however, put upward pressure on prices. Inflation, as measured by the Consumer Price Index (CPI) is estimated to have increased by 4.6 percent in 2004 with a large rise in the price of nontradable goods, in particular, rents which account for 36 percent of the CPI. ${ }^{3}$

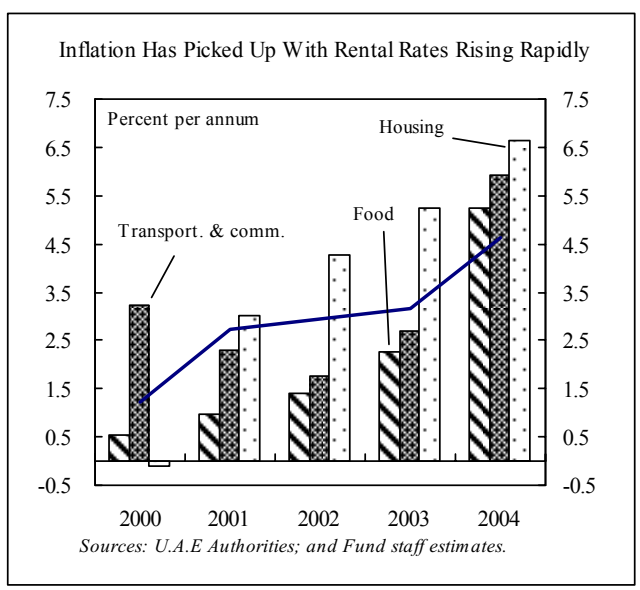

\footnotetext{
${ }^{2}$ The upward revisions, among other factors, reflect updated information on electricity and water, trade, and tourism sectors. Also, the significant upward revision in the growth rate of the construction sector reflects the results of a 2003 survey.

${ }^{3}$ A number of shortcomings affect the CPI, including: outdated weights, lack of imputations for missing data, and period differences between the base price and expenditure weights. Unofficially, it has been reported that rent which accounts for about 36 percent of the CPI basket has increased by 20 percent in 2004.
} 


\section{External sector}

12. The sharp rise in oil prices and strong non-oil export growth contributed to a large external current account surplus in 2004, of about 12 percent of GDP.

Hydrocarbon export earnings increased by 28 percent; and nonhydrocarbon exports and re-exports increased by about 18 percent (Table 2). The jump in free zone exports and re-exports reflected increased activity with respect to major markets for Dubai's free zones, namely, Saudi Arabia, Iran, and Iraq. The strong economic performance in the nonoil sector and the boom in the construction sector resulted in higher imports, which grew by 18 percent to $\$ 54$ billion.

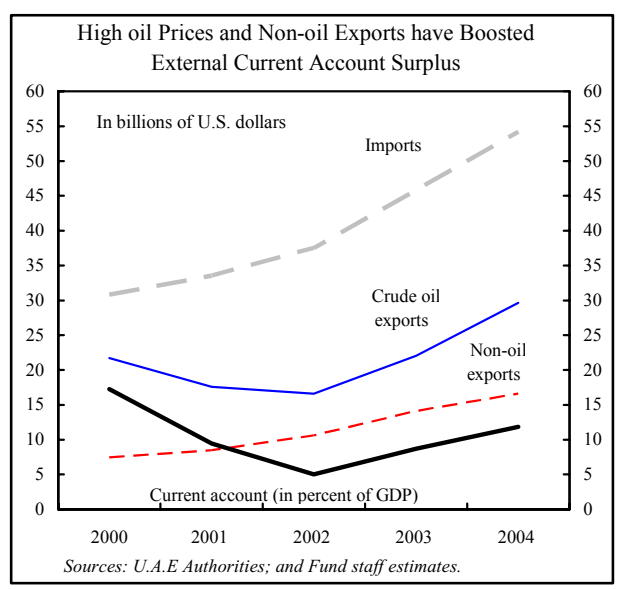

\section{The financial account balance is estimated to have registered a net} outflow of about $\mathbf{\$ 1 1}$ billion due mainly to placements of official capital abroad. FDI increased significantly since 2001 , in particular from the GCC countries. It is estimated that net FDI reached about $\$ 9$ billion in 2004. The overall balance of payments registered a surplus of $\$ 3.5$ billion.

\section{Fiscal policy}

14. The budgetary system of the U.A.E. continued to impede a timely and accurate assessment of overall fiscal developments. With a lack of uniformity among the seven Emirates and the Federal government in the classification of expenditures and revenues, the unavailability of data on government's investment income, and considerable netting out of fiscal operations at the Emirate level, comprehensive analysis of the fiscal developments remains difficult. Nevertheless, the availability of data on net accumulation of government foreign assets allowed the staff to prepare the overall fiscal accounts from the financing side.

\section{The fiscal position of Abu Dhabi improved considerably in 2004 on} account of high oil revenues and moderate expenditure increases. A significant part of the increase in oil revenues was saved as part of official assets held abroad. Also, the government restructured some of its ministries, downsized the workforce in the municipalities, and outsourced some of the services delivered by the municipality to the private sector. Subsidies were reduced further, mainly due to a continued decline in agricultural subsidies. ${ }^{4}$

\footnotetext{
${ }^{4}$ The analysis of 2004 subsidies of Abu Dhabi Finance excludes the amount of AD 1,261 million, a one-time settlement, paid to Abu Dhabi Water and Electricity Authority for settlement of the 1999-2002 accounts.
} 
16. The two other key Emirates, Dubai and Sharjah, maintained their policy of executing a budget that is largely in balance. However, a comprehensive assessment of Dubai's fiscal performance is limited by the fact that considerable fiscal operations are carried out outside Dubai's budget, and information on these operations is currently not available.

17. The Federal government, which also largely follows a balanced budget, benefited from various efficiency improving measures in 2004, such as performance based budgeting. ${ }^{5}$ While still depending on the Emirates' contributions for revenues, the revenue base from other sources such as fees and charges continued to rise, especially with higher royalties from the telecommunications sector in 2004. This trend is expected to further improve as service fees are restructured to be benchmarked to the cost of the respective services. On the expenditure side, the activities of the health services department related to Abu Dhabi were transferred to the Abu Dhabi government, which took over the management and financial

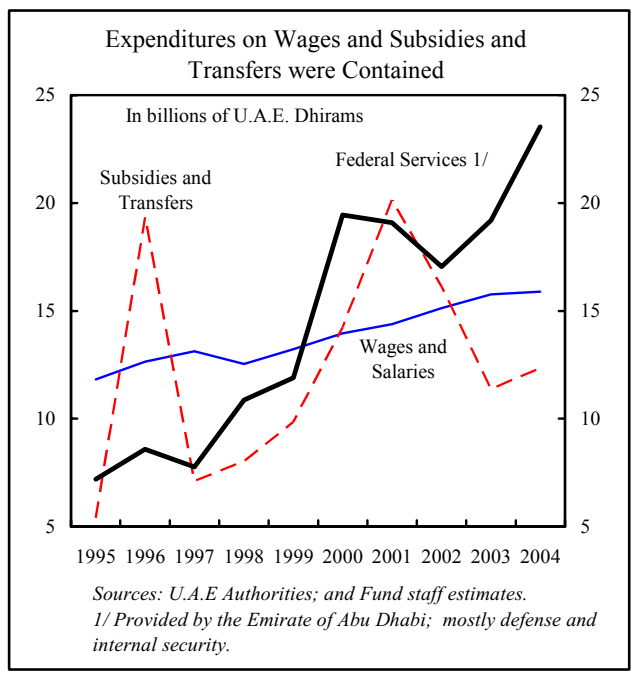
responsibility of this unit.

\section{The consolidated fiscal balance}

(fiscal accounts of the Federal government and the three largest Emirates) is estimated to have reached a surplus of $\mathbf{1 8 . 3}$ percent of GDP compared to 13 percent of GDP in 2003 (Table 3). Excluding investment income, the nonhydrocarbon fiscal deficit is estimated to have narrowed by about 4.5 percent of GDP, to 18.3 percent of GDP, mainly on account of lower expenditures.

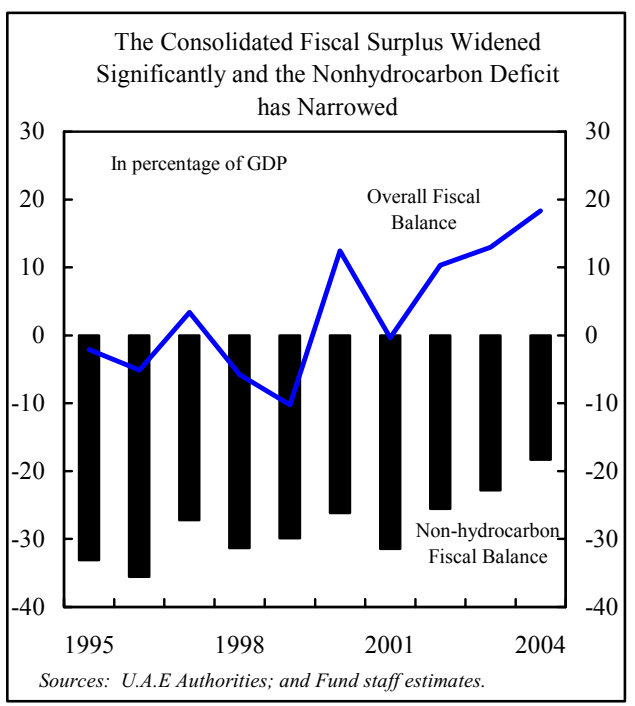

\footnotetext{
${ }^{5}$ Further IMF technical assistance in this area has been requested.
} 


\section{Monetary developments}

\section{Strong economic activity and high} capital inflows resulted in a significant increase in broad money ( 23 percent). ${ }^{6}$ The monetization was accompanied by a strong expansion in credit to the private sector, which increased by 24.7 percent in 2004 compared to 13.5 percent in 2003 (Table 4). Much of the private sector credit consisted of loans to the wholesale trade sector and personal loans for business. Domestic interest rates largely moved in tandem with U.S. rates.

\section{Financial developments}

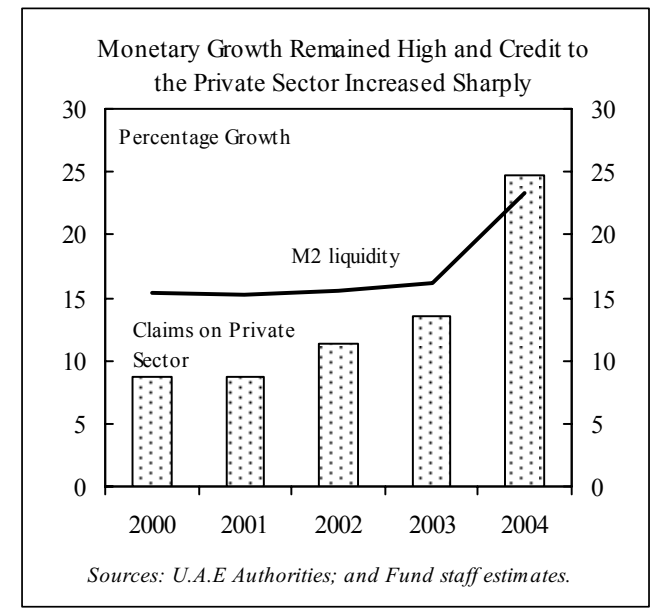

\section{The banking sector in the U.A.E remains strong, bolstered by effective} supervision, sound lending practices, and a vibrant economy. At end-2004, while the official ratio of nonperforming loans (NPL) to total loans remained somewhat high at 12.5 percent $^{7}$, provisions were considerable, bringing the net NPL ratio below 4 percent (Table 5). Overall, the capital-assets ratio (CAR) declined slightly to just under 17 percent, as banks increased their lending activities, but remains well above prudential norms for all banks.

\section{Banks' exposures to the booming real estate sector have so far been} limited. ${ }^{8}$ Most real estate buyers make cash purchases, while banks continue to be reluctant to lend more than 70 percent of the value of the property. At end-2004, banks' direct lending as a percent of total loans for real estate declined to 4.7 percent from 5.4 percent in 2003. Lending to the construction sector grew by 18 percent during 2004, though as a percent of total lending it declined to 12.8 percent from 13.6 percent. Information on the nonbank financial sector exposure to the real estate sector is not available.

\footnotetext{
${ }^{6}$ Starting in mid-2001, the CBU started to include deposits of U.A.E. residents booked in overseas branches/subsidiaries of locally incorporated banks in the measurement of broad money. During the 2005 Article IV mission, the authorities indicated that they will look into staff's recommendations to exclude these deposits from broad money statistics. Staff presentation and discussion of monetary developments are based on internationally accepted standards that exclude such deposits.

${ }^{7}$ Most of these loans are loans from the 1980s and early 1990s that remain on the books because of laws that do not allow for the writing off of loans as long as there is a chance that they will be repaid.

${ }^{8}$ In the absence of available data on the real estate market, the staff was not able to assess developments in this sector. Unofficially, it is reported that real estate prices have doubled in the past two years.
} 
22. The U.A.E. securities markets, the Abu Dhabi Securities Market (ADSM) and the Dubai Securities Market (DSM), have witnessed significant growth since their inceptions in 2001 (Box 2). Total market capitalization tripled to slightly over $\$ 82$ billion, while the cumulative value of the shares traded increased from $\$ 2$ billion in 2003 to $\$ 18$ billion in 2004. The $\mathrm{P} / \mathrm{E}$ ratio in ASDM increased from 13 percent to 22 percent during the same period. The composite index of the two markets increased by 88 percent in 2004 , after having increased by 32 percent in $2003 .{ }^{9}$

23. Supervision of securities continues to be strengthened by making the Emirate Securities and Commodities Authority (ESCA) operational, increasing its staff and providing those staff with training. Also, listing and disclosure requirements have been clarified, effectively eliminating the "Over the Counter" market. Transparency has been strengthened by publishing some major laws and circulars on the internet, and by maintaining a continuous two way dialogue with banks on supervision, laws, and regulations.

24. Major steps have been taken to put in place a strong legal framework to prevent money laundering and financing of terrorist activities. Two laws were passed in 2004, one on dealing with financing of terrorism and the other addressing AML/CFT issues in the financial free zones. A law criminalizing money laundering that was adopted in 2002 has been widely cited as a model of best practices. Hawala dealers continue to voluntarily register and have been certified by the CBU. As of end-February 2005, the CBU has received 156 registration applications and 133 certificates have been issued.

\section{The Dubai International Financial Center (DIFC) began operations in}

September 2004. As of mid-March 2005, 11 financial institutions have been granted licenses to operate within the free zone. It is expected that this number will rise to about 50 by endyear. Also, considerable progress has been made with respect to the regulatory framework governing the DIFC, and an extensive set of laws has been established based on best international practices.

\section{REPORT ON DISCUSSIONS}

\section{A. Near- and Medium-term Outlook}

26. Based on the latest World Economic Outlook (WEO) oil price projection, large fiscal and external current account surpluses are projected in 2005.

Nonhydrocarbon GDP growth is projected at about 7 percent supported mainly by strong growth in the manufacturing, transport, and construction sectors. Reflecting the price pressure in the nontradable sector, the CPI is projected to reach 6 percent.

\footnotetext{
${ }^{9}$ As of mid-May 2005, the composite index of the U.A.E. has increased by over 75 percent since the beginning of the year.
} 


\section{Box 2: U.A.E. Securities Market}

The growth in the U.A.E. securities market can be traced to a number of factors, including: (a) shift of funds from abroad to the region in the aftermath of $9 / 11$; (b) an increase in the number of listed companies (from 15 companies at end-2001 to 55 companies by March 2005); (c) strong profitability of quoted companies (banks' profits grew by about 40 percent in 2004); (d) weak performance of the international markets; (e) the opening up and privatization of a number of sectors, such as real estate; and finally (f) low interest rates in the country.

Notwithstanding recent developments, the U.A.E. markets are relatively shallow, concentrated, and retail based. Only 5 companies made up over 60 percent of the total value of trade at end-2004 in ADSM. Changes in the prices of one real estate company, was responsible for half of the market index increase in DSM, while changes in the price of a communication company, resulted in about half of the increase in ADSM index. The role of institutional investors remains limited, in part because of prohibition on purchase of own shares by listed companies, lack of corporate retirement schemes, and a lack of market makers and underwriters.

Banking sector's direct exposure to the equity markets other than IPOs was limited in 2004 at about 1.8 percent of total banking system's loan portfolio. CBU regulations limit total bank lending to 100 percent of total stable resources. ${ }^{1}$ Other CBU regulations place caps on bank financing of IPOs and purchases of securities. Nonetheless, banks' exposure to the securities market through the financing of IPOs grew significantly in 2004, prompting the CBU to issue circulars requiring banks to strictly observe the regulations, and also not to lend more than 5 times the margin provided by customer for subscribing to new IPOs.

1/ Defined as the sum of own funds, interbank deposits greater than 6 months, and total customer deposits.
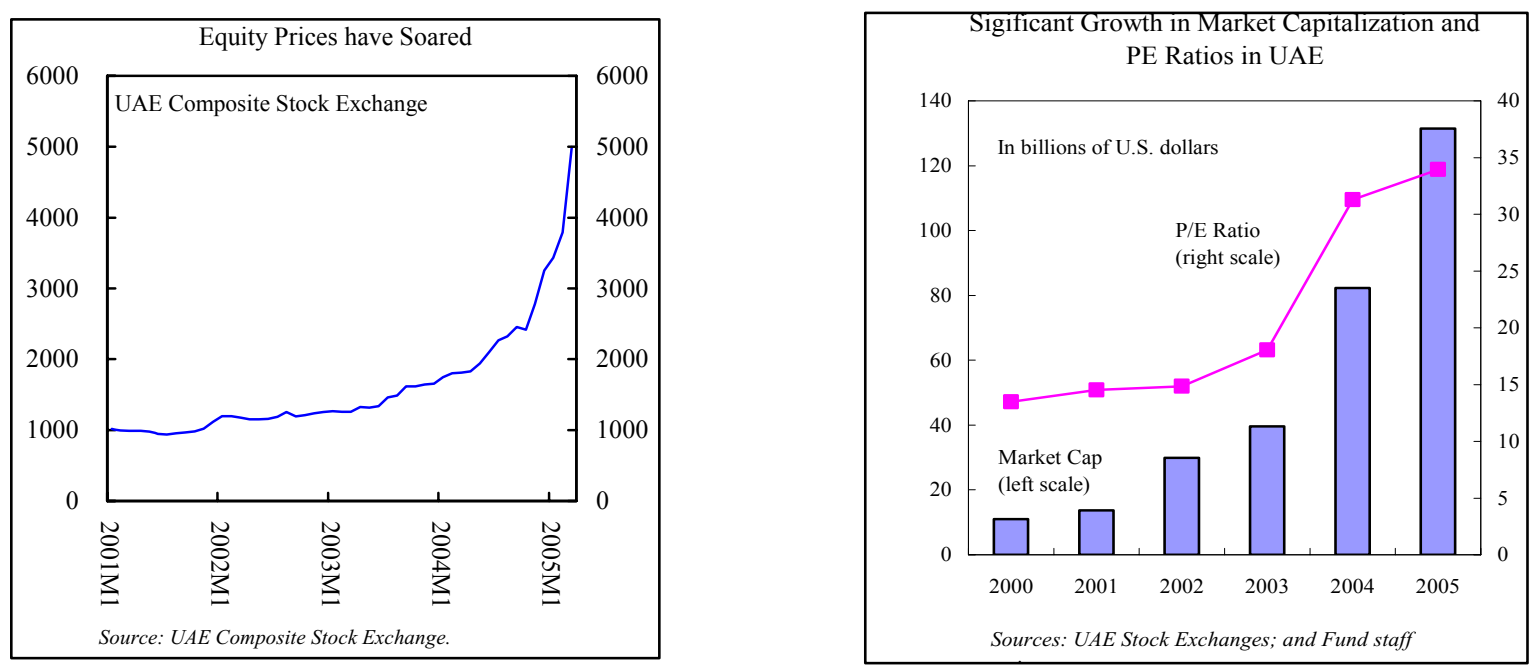

27. Since the return of the mission on March 30, the President of the U.A.E, Sheikh Khalifa bin Zayed Al Nahyan, announced an increase in salaries (25 percent for nationals and 15 percent for non-nationals) for Federal and Abu Dhabi's government employees. The other major Emirates have followed suit. The staff's preliminary assessment indicates that 
the fiscal impact from the proposed salary increase will be limited to 0.5 percent of GDP. ${ }^{10}$ However, the staff is of the view that the stimulus impact of this measure will add to the inflationary pressures already in the system and would increase the reservation wage in the public sector. The latter would adversely affect the incentive structure and discourage nationals to seek jobs in the private sector.

\section{In discussions with the authorities during the spring meetings, the staff was} informed that political pressure has been mounting for some time to increase salaries and that with the sustained rise in oil prices the political leadership felt that there is a need to transfer part of the windfall from oil to the population. As for the economic impact of this measure, they were of the view that while the fiscal impact would be minimal they stood ready to tighten monetary conditions if needed.

\section{The medium-term outlook remains favorable based on current} expectations that world oil prices will remain high ${ }^{11}$ and oil production will increase steadily to more than 3 million barrels per day by 2010 (Box 3). Real nonhydrocarbon GDP growth is projected to remain robust as the economy gains traction from the ongoing productivity enhancing structural reforms, improved investment regime, and a more streamlined business climate. During 2006-10, both the fiscal and external current account balances are projected to continue to register large surpluses averaging about 22.5 percent and 17 percent of GDP, respectively (Table 6).

\section{Although the medium-term outlook is based on historically high levels of} oil price and production assumptions, the downside risks to the projected outlook from a drop in oil prices are somewhat limited. The staff estimates that the overall fiscal position will remain in balance with oil price as low as $\$ 23.3$ per barrel during 2005-10. ${ }^{12}$ However, there are additional risks in the system that warrant close monitoring, in particular, soaring asset prices and accelerating inflationary pressure, especially if reported inflation is under estimating actual inflation. ${ }^{13}$ Also, sudden shifts in global interest rates could dampen current investor confidence.

\footnotetext{
${ }^{10}$ A blanket increase (25 percent for nationals and 15 percent for non-nationals) would amount to US $\$ 0.6$ billion or 0.5 percent of GDP. The consolidated fiscal surplus would continue to register a surplus of 22.6 percent of GDP in 2005.

${ }^{11}$ In line with the April 2005 WEO projections, oil prices are projected to decline only marginally to an average of $\$ 45.8$ between $2006-10$.

${ }^{12}$ The staff estimates that for each $\$ 1$ drop in the price of barrel of oil, on average, the fiscal balance will weaken by about 1 percent of GDP during 2005-10.

${ }^{13}$ See Footnote 3.
} 


\section{Box 3. Recent Developments in the Oil Market and Prospects for the U.A.E. Hydrocarbon Sector}

Recent developments in the global oil market: World oil markets since mid-2003 have been driven by strong

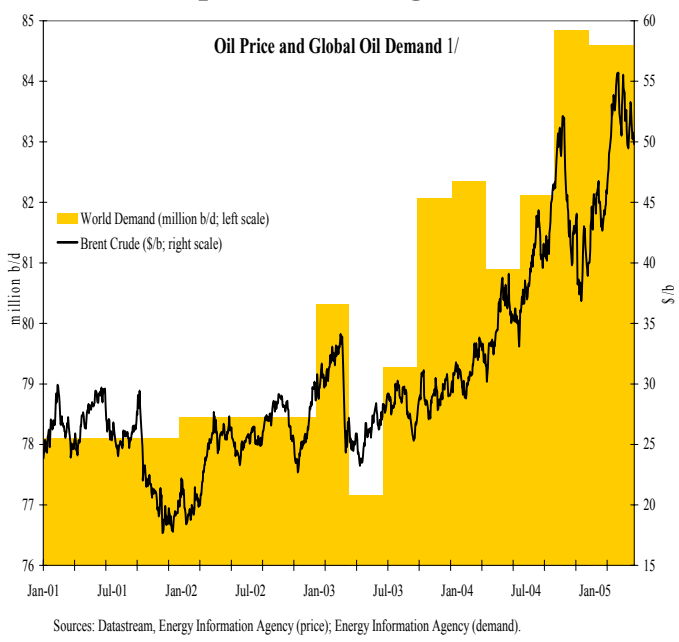
global demand growth of 3-4 percent, dwindling surplus capacity, tightness in refining and shipping capacity, concerns about potential supply disruptions in several key producing countries, and increased speculation by financial investors. Demand growth was particularly strong in China, due to strong economic growth, coal shortages, and heavy oil infrastructure investments.

The April World Economic Outlook (WEO) oil price projection puts the average in 2005 at $\$ 46.5$ per barrel, up from just under \$29 per barrel in 2003 and \$37.8 in 2004.

Prices are projected to stay high in the coming years. However, there have been no physical shortages of oil, as OPEC lifted oil production quotas several times since June 2004, and most OPEC members have been producing well above their quota. However, there are still concerns about a market mismatch regarding the crude oil qualities demanded and supplied. International oil markets are short of light sweet crude; while there have been signs of an oversupply of heavy sour grades, particularly from Arab oil producing countries. While oil market conditions will remain tight in the near future, there are also indications of easing in the medium term, as demand growth is projected to slow markedly and significant new production capacity (both within and outside OPEC) will come on stream in the coming years.

Prospects for the U.A.E. hydrocarbon sector: With a production close to capacity at about $2.5 \mathrm{~m} \mathrm{~b} / \mathrm{d}$, the U.A.E. currently rank as the $9^{\text {th }}$ largest crude oil producer and $6^{\text {th }}$ largest net oil exporter worldwide. However, the country's role in the global oil market will certainly increase further in the future, as its oil reserves amount to nearly 10 percent of the world total. Presently, Abu Dhabi is embarking upon large scale expansion projects which will lift the U.A.E.'s oil production to about $3 \mathrm{~m}$ b/d in 2010 and to up to $4 \mathrm{~m} \mathrm{~b} / \mathrm{d}$ in the longer term. At the same time, continued massive investments in natural gas production and infrastructure will —in combination with gas imports from Qatar-satisfy the country's rapidly rising domestic gas demand (for electricity generation, petrochemical feedstock, and reinjection into oil fields) and create new potentials for the exportation of condensates and natural gas liquids. Industry sources estimate total investment in the U.A.E.'s hydrocarbon sector at more than $\$ 30$ bn over the next ten years. Unlike most Gulf oil producing countries, international oil companies participate

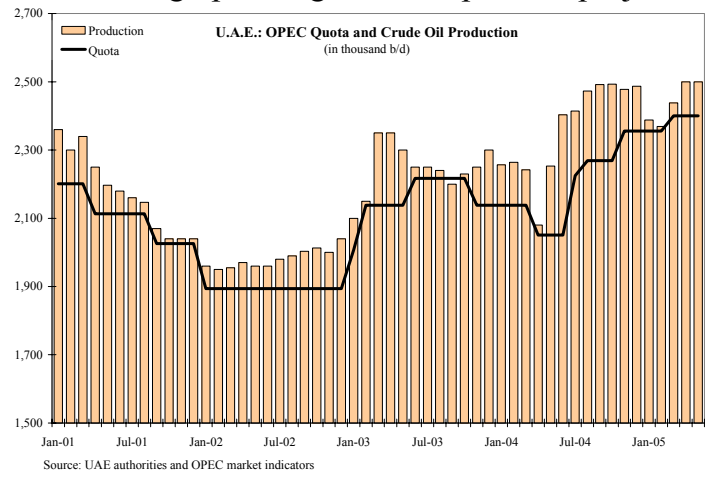
in the U.A.E.'s hydrocarbon sector, both sharing the burden in funding enhanced oil recovery projects and capacity expansions and providing state-of-the-art technology.

\section{B. Policy Discussions}

31. The sustainability of U.A.E.'s growth prospects hinges on both the continued implementation of structural reforms and on maintaining financial stability. These 
reforms should aim at improving the budget structure and fiscal coordination among the Emirates and the Federal government, promoting private investment by lifting remaining impediments to foreign investments outside the free zones areas, and enhancing the long-run employability of the national labor force through training and education. Also, financial policies might need to be tightened to contain inflationary pressures.

32. To reinforce government's policies already in place and to address some of the above issues, the staff stressed the need for better coordination among the Emirates and the Federal government. The staff also underscored the importance of enhancing transparency, particularly in the fiscal area, in order to improve the policymaking environment and to ensure that the fiscal policy stance is consistent with overall macroeconomic objectives. The staff also reviewed risks and developments in the financial sector and assessed performance in following up on the remaining recommendations of the 2001 FSAP mission (Appendix IV).

\section{Macroeconomic Policies}

\section{Fiscal policies}

33. Fiscal policy coordination among the Emirates and the Federal government remains weak, and standardization of their accounting systems is still piece-meal. There is also considerable netting out of fiscal operations at the Emirates level. ${ }^{14}$ Against this backdrop, discussions of fiscal policies were conducted separately at the Federal level and with the Emirates, anchoring on Abu Dhabi's fiscal policies and the public administration reforms of the Federal government. Reforms on key issues such as widening the tax base on a Federation-wide scale and reducing subsidies on water and electricity in Abu Dhabi were also discussed.

\section{The government of Abu Dhabi continues to manage its hydrocarbon} receipts by setting the budget at a relatively conservative oil price ( $\$ 28$ per barrel in 2005), while saving and investing most of its fiscal surpluses abroad through its main investment arm, Abu Dhabi Investment Authority (ADIA). Also, the government has taken a number of measures to contain current expenditures, in particular subsidies on agriculture and to streamline the wage bill through a combination of downsizing of employment and corporatization of certain services. The recent wage increase is expected to add about 0.11 percent of GDP to Abu Dhabi's wage bill.

35. The U.A.E.'s Federal government continues to play an important role in the federation and often leads in public administration reforms. However, its own finances are constrained and revenue limited to some fees and charges and block

\footnotetext{
${ }^{14}$ It seems that most off-budget operations appear to be undertaken on a commercial basis, which reduces the risk of inefficiencies and misallocation of resources.
} 
transfers from the Emirates of Abu Dhabi (mainly) and Dubai that have been constant over time.

36. The authorities informed the staff that the Federal government is currently developing a framework for better policy coordination among the Emirates. To this end, a new economic planning committee has been formed to improve coordination across the Emirates on these fronts. This could bring about uniformity in the budget classifications and enhance analysis of fiscal policy.

\section{The consolidated fiscal position ${ }^{15}$ is projected to remain in significant} surplus over the medium term. Also, the fiscal position is sustainable for the foreseeable future under the current baseline scenario, based on the intergenerational equity objective of maintaining net wealth constant in real terms. If oil prices were to decline to $\$ 25$ per barrel, the annual fiscal adjustment needed to maintain net wealth constant in real terms would be on average about 1 percent of 2005 GDP for the 2005-10 period. While implicitly financial savings from the government's oil revenues are based on the objective of saving for future generations, the authorities do not explicitly follow the inter-generational equity objectives of maintaining net wealth constant over time. In discussions with the authorities in the Emirate of Abu Dhabi, they indicated that they will continue to prepare their budget on a conservative oil price assumption.

38. The fiscal policy stance as measured by the nonhydrocarbon fiscal deficit (excluding investment income) as percent of nonhydrocarbon GDP indicates a narrowing trend since 2001. Nonetheless, given the limitations of monetary policy under a fixed exchange rate system, the burden of tightening financial policies to stem inflationary pressure will likely fall on fiscal policy. This task, however, is complicated by the decentralized fiscal policy structure in the U.A.E.

39. In the period ahead, pressures may build for an increase in expenditures to address the emerging unemployment and potential unfunded pension liabilities. Accordingly, the staff recommended that steps be initiated to strengthen the structure of the budget.

40. On the revenue side, the staff recommended broadening the tax base by extending the corporate income tax to the nonhydrocarbon sector, and introducing a value-added-tax (VAT) system. ${ }^{16}$ A VAT system will allow the Federal government to reduce its dependence on charges and fees. The authorities agreed on the need to broaden the tax base and informed the staff that discussions on

\footnotetext{
${ }^{15}$ Consolidated fiscal accounts of the federal government, Abu Dhabi, Dubai, and Sharjah.

16 Apart from a profit tax on oil and gas companies, a corporate income tax of 20 percent on foreign banks, and low import tariffs, the U.A.E. has no other sources of tax revenue.
} 
the introduction of the VAT have gained momentum at the cabinet level. To pave the way for the introduction of the VAT, the authorities have requested Fund's technical assistance. Also, the Emirates should consider introducing a property tax.

41. On the expenditure side, the staff welcomed the further reduction in agricultural subsidies in the Emirate of Abu Dhabi and recommended that the government of Abu Dhabi continue to enhance the efficiency of its power and utility sector through privatization and gradually reducing subsidies on water and electricity. While the recent announcement of the wage increase for 2005 by the Federal government, followed by the individual Emirates, is unlikely to dent the fiscal situation, it amplifies lingering concerns over the issue of policy coordination among the Emirates and the Federal government.

\section{Monetary policy and the financial sector}

42. In the context of the fixed exchange rate system and full capital account convertibility, the authorities agreed with the staff that the effectiveness of monetary policy is limited. Local interest rates are closely aligned with the U.S. dollar rates, and the main monetary instrument currently used by the CBU to smooth out fluctuations in domestic liquidity is certificates of deposits (CDs). The staff welcomed the CBU's plans to issue CDs with longer maturities of up to 60 months, which would broaden the availability of instruments to mop up liquidity and facilitate the development of a repo market based on CDs.

43. Due to continued projected capital inflows, money supply growth is projected to remain high in $\mathbf{2 0 0 5}$. The staff recommended that the authorities tighten credit conditions to slowdown credit growth to the private sector and contain pressures on the prices of nontradables. The authorities agreed with the staff's recommendations and indicated that consideration was being given to raising reserve requirements on demand deposits. The staff also recommended introducing tighter prudential norms, including higher provisioning rates for specific types of credit instruments, such as credit cards, higher required down payments, and stricter collateral requirements on loans.

44. There is a need for full rationalization and consolidation of regulatory oversight related to capital markets and nonbank financial intermediaries. Most importantly, the CBU and ESCA will need to coordinate closely to ensure that a comprehensive supervisory framework for the entire financial sector is in place. The authorities agreed with the staff's recommendations that they request a Reports on Standards and Codes (ROSC) mission, from the Fund, which was not conducted during the 2001 FSAP.

45. The staff stressed that laws and regulations pertaining to investment and finance companies will need to be strengthened, and gaps need to be addressed in order to safeguard investor interests. The staff welcomed the CBU's role in ensuring that banks are adequately shielded from market risk associated with their 
investment companies. However, staff stressed that the 1994 Law on Investment Companies needs to be updated to ensure that they are in full compliance with the International Organization of Securities Commission areas of regulatory concern and risk assessment methods, such as proper and disclosed basis for asset valuation, suitability of investment schemes, and pricing.

46. The DIFC has made considerable progress in developing a regulatory framework that follows best international practices. The unique nature of the governance relationships involved, and the broad scope of its activities raise some concern about what risks are being created and what effects, if any, there may be on the monetary system of the U.A.E. ${ }^{17}$ The authorities in the U.A.E. and DIFC have agreed with the staff that it would be useful to have the operations and regulatory arrangements of the DIFC assessed by the Fund. A mission for that purpose could potentially take place in late 2005 or early 2006.

\section{Structural Policies}

\section{Restructuring and privatization}

47. The staff welcomed the broadening of FDI opportunities in the export free zones in Dubai. However, it stressed that equally important in promoting foreign direct investment is the establishment of an unambiguous legal framework for the private sector. In this regard, the staff urged the authorities at the Federal and Emirate levels to implement FDI legislation that is market-based and tailored to allow individual Emirates to pursue their respective economic development strategies. The authorities agreed with staff's recommendation and noted that, in line with efforts to continue the process of economic diversification, the U.A.E. is amending the Commercial Company Law, applicable across the federation, which may see the ceiling on foreign ownership raised from the current 49 percent.

\section{The creation in 2004 of the Dubai International Arbitration Centre} (DIAC) is also a welcome development. This institution is based on International Chamber of Commerce rules and has the potential to help solve business disputes quicker and foster international trade and investment. The authorities informed the staff that the Dubai Chamber of Commerce and Industry is also preparing to establish a credit rating and reporting agency (affiliated with an international credit agency) that will operate in the U.A.E. and eventually GCC wide.

\footnotetext{
${ }^{17}$ Since both the operating and regulatory arms of the DIFC are subordinate to the Government of Dubai, the governance structure holds the potential for conflicts of interest regarding regulations. Also, since nationals are allowed to open non-dirham investment accounts and borrow in foreign currency from the DIFC, the impact of these operations on monetary developments needs to be monitored closely.
} 
49. The privatization of Abu Dhabi's utilities sector is proceeding as planned. In 2004, one power plant was sold to private investors. Further privatization of the remaining three state-owned power generation companies and the two power distribution companies is being considered. The staff is of the view that the implementation of the privatization plan of Abu Dhabi's water and power sector could act as a catalyst for broadening the role of the private sector and for gradually reducing electricity and water subsidies. ${ }^{18}$ In this connection, the staff welcomed the elimination of some subsidized tariffs, such as those for government buildings, and the plan to gradually install water meters in all households.

\section{Labor policies}

50. The staff stressed that it is critical that any future changes to labor policy do not adversely impact the competitiveness of the economy. So far, most of the jobs in the private sector have been filled by expatriate workers, with the majority of nationals continuing to seek employment in the public sector. As a result, the authorities have implemented a string of new measures in recent years to increase the cost associated with hiring expatriate workers (Box 4). The liberal labor policies adopted thus far in the U.A.E. have allowed the private sector to recruit expatriate workers at internationally competitive wages. These policies have contributed to the economic growth and improved competitiveness of the non-oil economy in the U.A.E., which in turn resulted in job creation for nationals.

51. Employment opportunities for nationals will need to be created through longterm structural policies in the areas of education, training, wage policy, and labor legislation. In this connection, the staff welcomed the measures taken by the authorities to create employment opportunities for U.A.E. nationals in the private sector.

\section{E. External Sector}

\section{The authorities noted that the pegged exchange rate regime has served} the U.A.E. economy well by providing a nominal anchor and strengthening confidence in its economic policy. They also indicated that the exchange rate credibility is further reinforced by the policy commitment toward the GCC monetary union by 2010. Reflecting developments in the dollar exchange rate, the real effective exchange rate (REER) (based on consumer prices) has depreciated by more than 13 percent during 2002-04, but has appreciated by about 20 percent since 1990 . The cumulative appreciation does not seem to have eroded competitiveness, the role of the private sector has been enhanced and the economy is among the most diversified in

\footnotetext{
${ }^{18}$ While nationals in Dubai enjoy water and electricity consumption at subsidized tariffs, the Dubai Electricity and Water Authority (DEWA) appears to be able to recover costs by charging the large expatriate population at commercial tariff rates.
} 
the GCC region. Also, since 1995, nonhydrocarbon exports have grown by over 20 percent per year.
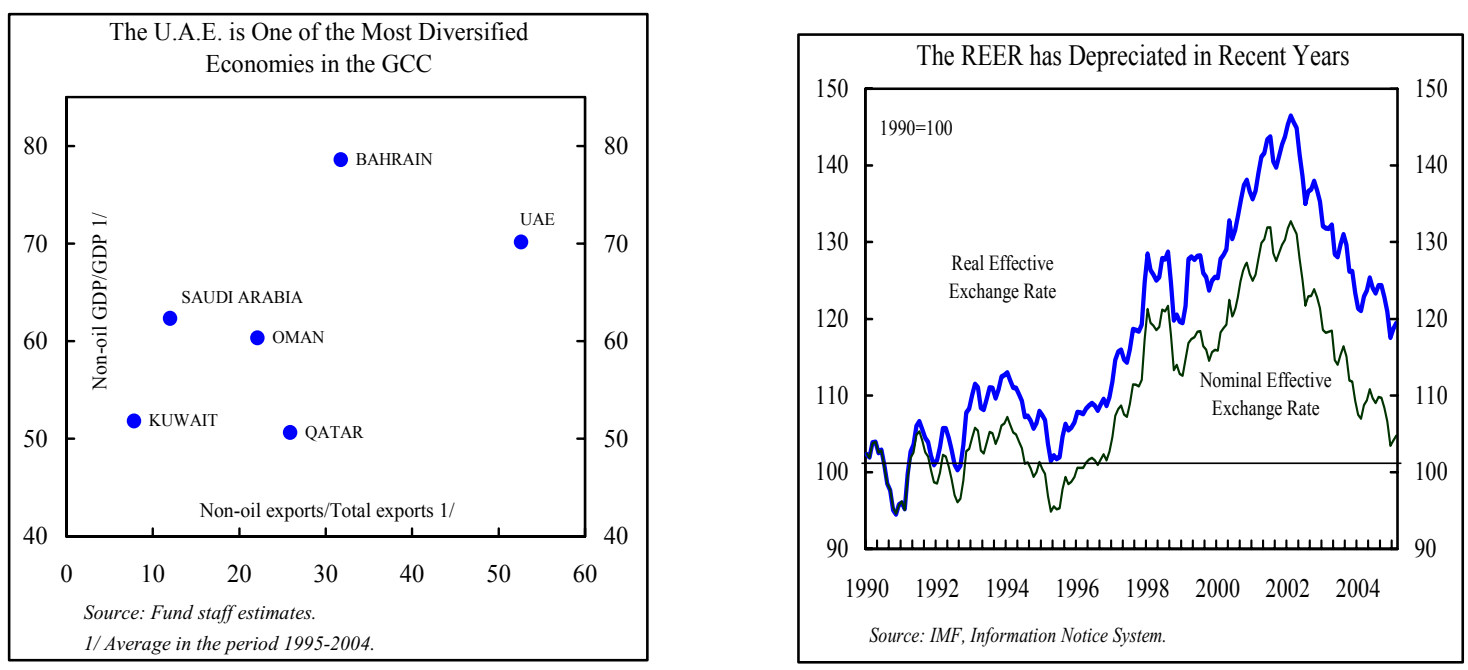

53. The authorities informed the staff that progress continued in regional integration. Negotiations are ongoing among the GCC countries to prepare a common list of items to be prohibited for security and religious reasons. In connection with the envisaged monetary union among the members of the GCC, deliberations are continuing on: (a) identifying issues that would need to be addressed in establishing a common central bank; (b) establishing a common data standard and a common fiscal accounting framework to facilitate the adoption of macroeconomic convergence criteria by 2005 ; and (c) identifying other areas that would need further harmonization.

54. Recently, the staff was informed that the governors of the GCC central banks and monetary agencies have agreed on five convergence criteria which are similar to those adopted by the European countries as part of the Maastricht Treaty in 1992. The proposed convergence criteria have been discussed at a recent GCC Ministerial Meeting and are expected to be presented for approval at the Heads of State Summit at end-2005 or early 2006.

55. The U.A.E. has continued to forge ahead with closer economic integration beyond the GCC countries. Recently, the U.A.E. signed a Trade and Investment Framework Agreement (TIFA) with the U.S., which is likely to pave the way for a more comprehensive Free Trade Agreement (FTA) in the next few years. The authorities stressed that due attention was being paid to the GCC customs union agreement as they prevail at present in their FTA negotiations with the U.S. Nonetheless, they indicated that in the period ahead all other FTAs would be negotiated at the GCC level. 


\section{Box 4: Labor Market Developments and Prospects}

During 1999-2004, reflecting the high increase of national population and the large influx of expatriate workers the U.A.E.'s population grew at an average rate of 7.3 percent a year, reaching 4.3 million by mid- 2004 . Nationals accounted for about 21 percent of the total population. For the same period, the economy created annually an average of 177000 jobs compared to 18000 annual increases in the national labor force.

On average, it is estimated that for each 1 percent growth in the non-oil economy, employment increased by about 1.4 percent during 1999-04. While economic growth was more than sufficient to absorb the new entrants to the labor force, unemployment among nationals increased gradually from 7.6 percent in 1999 to 11.4 percent in 2004. The total number of unemployed nationals reached 29,000 .

Nationals continue to have a strong preference to be employed in the public sector for three main reasons: (i) the high wages offered in the government sector, which, on average, the nationals cannot obtain in the private sector; (ii) the relative lack of marketable skills of nationals to compete with inexpensive expatriate labor employed in the private sector; and (iii) shorter working hours and other nonwage benefits.

The authorities have taken a number of important steps to address the rising unemployment among nationals and to increase their employment in the private sector. They include: (a) training and job placement programs to match the needs of the private sector; (b) job counseling, including public awareness programs at the secondary school and higher education levels; (c) enactment of a pension plan for nationals working in the private sector in a plan equivalent to that which applies to the public sector; (d) entrepreneurship programs that provide funds at low rates to nationals for them to start their own businesses; (e) increasing the cost of expatriate labor through higher visa charges and other fees; and, (f) Emiratization through quotas for nationals in targeted sectors (banking, insurance, and more recently, trade).

U.A.E.'s general policy has been to avoid straining private sector resources by imposing wide-ranging employment quotas for nationals. This is a welcome policy because of the significance of expatriate labor's contribution to growth and to maintaining the competitiveness of the economy. Some additional measures that could be considered include: (a) orienting the education system toward encouraging the nationals to acquire skills that are more marketable in the private sector; (b) taking measures to equalize the number of work days and work hours in the private and public sectors; (c) providing unemployment benefits to nationals who work in the private sector; and (d) minimizing restrictions on expatriate job mobility to enhance labor market efficiency, which could also result in an increase in non-nationals' wages and improve the competitiveness of nationals.

\section{STATistical Issues}

56. The staff welcomed the authorities' cooperative approach in the provision of detailed estimates of official foreign assets of the government. Some measures to improve the institutional statistics framework have been initiated. In particular, the members of the Inter-Ministerial Statistical Committee (SC) consisting of statistical directors from all Emirates as well as from Federal government ministries have met six times during the past year. A GDDS coordinator has been identified at the Ministry of Economy and Planning (MOEP), but no nomination has yet been made. The 2005 population census is in the preparation phase, and the authorities plan to 
carry out standardized country-wide Household Budget Surveys and sectoral Business Establishment Surveys based on the census results.

57. The staff stressed that the U.A.E.'s economic statistics continue to suffer from numerous structural weaknesses with respect to data quality, coverage, periodicity, timeliness, and inter-sectoral consistency. Data compilation and reporting are hampered by a shortage of trained staff and poor coordination within and between Emirates and Federal government agencies. These shortcomings have imposed severe constraints on economic monitoring, analysis, and policy formulation for both the authorities and the staff.

58. The staff also stressed that, looking forward, there is a need to adopt a consistent and comprehensive set of public sector fiscal accounts using a common methodology across the individual Emirates and the Federal government budget systems. In preparation for the GCC-wide monetary union by 2010, issues related to fiscal convergence criteria will need to be addressed. As such, consolidated fiscal accounts for the seven Emirates and the Federal government based on harmonized classifications and methodologies will need to be developed and be available without significant delay.

59. The staff recommended that, in the near term and until the SC becomes more active, progress could be made by strengthening the current institutional base that exists at the CBU and the MOEP for the compilation of financial, national, and price statistics. To address fiscal data issues, a Committee of Fiscal Policy Coordination should be formed within the Ministry of Finance and Industry to provide coordination between the Federal government and the seven individual Emirates with respect to the harmonization of classification and methodology.

\section{Staff Appraisal}

60. An outward-oriented development strategy and prudent financial policies have resulted in impressive economic growth over the years and have led to large accumulation of external financial assets. As a result, economic diversification has advanced rapidly, supported by an increasing role of the private sector. Also, openness, sustained investment in physical and social infrastructure, and a good record in macroeconomic management have laid the foundation for further economic and social progress in the period ahead.

61. The combined effect of surging oil and non-oil exports, strong domestic demand, and booming stock and real estate markets have created much optimism on the economic front. Also, given the projected favorable prospects in the global oil market in the medium term, economic developments are projected to remain strong. Both the fiscal and external current account balances are projected to register large surpluses. However, over the medium term, pressures may build up for an increase in expenditures to address the emerging unemployment pressures and unfunded pension liabilities. 
62. The staff recommends measures to strengthen the structure of the budget. On the expenditure side, government employment should be contained and rewards increasingly based on productivity. Subsidies on water and electricity should be phased out and replaced by targeted payments to nationals below a certain income. The revenue base could be broadened by introducing a VAT system at the Federal level and the Emirates could consider introducing a property tax. In this connection, the staff supports the authorities request for technical assistance from the Fund for the introduction of a VAT system.

63. To improve fiscal policy assessment, there is an urgent need to enhance the flow of data among the Emirates and the Federal government. The staff urges the authorities to give high priority to improve the compilation of statistics on consolidated government activities, the absence of which undermines the authorities' and the staff's ability to monitor macroeconomic developments. Also, given the autonomy of Emirate governments in public finance matters, the staff is of the view that better coordination in setting policy objectives and implementation among Emirates would enhance efficiency of the overall economy.

64. Credit conditions should be tightened to contain inflationary pressures. To this end, consideration should be given to raising reserve requirements and tightening certain prudential norms. However, in view of the exchange rate peg and full capital account convertibility, the effectiveness of monetary operations in easing inflationary pressures is likely to be limited. Thus, a further tightening of fiscal policy by targeting a lower nonhydrocarbon fiscal deficit might be needed.

65. The U.A.E. banking system is financially sound, well managed, and effectively supervised. The staff commends the authorities for strengthening the prudential regulations and supervision, including the implementation of some of the FSAP recommendations. However, there is a need for full rationalization and consolidation of the regulatory oversight related to the capital markets and nonfinancial bank intermediaries. Also, regulations pertaining to investment and finance companies will need to be strengthened and gaps need to be addressed in order to safeguard investor interests.

66. The surge in asset prices, although partly backed by strong economic fundamentals, is an area that warrants closer monitoring. While direct exposure of the financial system to the equity and real estate markets remains limited, a significant increase in credit to the private sector in 2004 might have been channeled to the equity markets. Also, in case of a correction in the equity markets, there could be an impact on households' balance sheets. To this end, the staff recommends that the authorities consider higher provisioning rates for specific types of credits, which carry higher than average risks, require higher equity participation for real estate and margin trading loans, and enforce stricter collateral requirements. Also, there is a need to put in place a system to start collecting information on nonbank financial sector exposure to the real estate market.

67. The pegged exchange rate arrangement continues to be supported by strong economic fundamentals, prudent macroeconomic management, and sound financial system. The strong non-oil export growth and the significant depreciation of the AED in real 
effective terms since 2003 also indicate that competitiveness is not a problem. The staff concurs with the authorities that the pegged exchange rate regime has served the U.A.E. economy well and welcomes their position to remain open toward the choice of the exchange rate regime under the planned monetary union. Since other exchange rate regimes with more flexibility would require greater institutional development, including in foreign exchange markets and risk management and intervention policies, staff urges the authorities to begin to formulate strategies to develop these areas at an early stage to keep their options open.

\section{In general, the staff agrees with the authorities' labor market strategy to} increase employment opportunities for U.A.E. nationals. This strategy should continue to rely on raising the skills of nationals through better education and training programs geared toward private sector labor demand, while avoiding mandatory measures, such as quotas. The staff also recommends the implementation of labor legislation reform to provide flexibility in hiring and firing of nationals. Also, reform of the current social benefits system to move toward equalization of wages in the private and public sectors is needed.

69. The staff strongly recommends that the needed budgetary resources and trained staff be secured to improve the collection, compilation, and reporting of fiscal, national accounts, balance of payments, and price statistics. There is also a need for the SC to finalize the GDDS metadata prepared together with the December 2003 Multi-Sector Mission from the Fund, and to formally nominate a GDDS coordinator. While data provision is adequate for overall surveillance purposes, data shortcomings have significantly affected the staff's analysis of some key issues in areas central to surveillance.

70. It is proposed that the next Article IV consultation take place on the standard 12-month cycle. 
Table 1. U. A. E. Selected Economic Indicators, 2000-05

\begin{tabular}{|c|c|c|c|c|c|c|}
\hline & 2000 & 2001 & 2002 & 2003 & $\frac{\text { Prel. }}{2004}$ & $\frac{\text { Proj. }}{2005}$ \\
\hline & \multicolumn{6}{|c|}{ (In billions of U.A.E. dirhams) } \\
\hline \multirow[t]{2}{*}{ GDP at market prices } & 259.2 & 255.4 & 275.3 & 325.1 & 382.7 & 469.3 \\
\hline & \multicolumn{6}{|c|}{ (In millions of barrels per day) } \\
\hline \multicolumn{7}{|l|}{ Oil production and exports } \\
\hline Crude oil production $1 /$ & 2.41 & 2.44 & 2.26 & 2.59 & 2.66 & 2.80 \\
\hline Of which: Condensates & 0.22 & 0.32 & 0.33 & 0.33 & 0.33 & 0.40 \\
\hline Average UAE crude price (US\$ per barrel) & 27.51 & 23.91 & 24.75 & 28.11 & 36.30 & 48.75 \\
\hline WEO oil price (US\$ per barrel) & 28.24 & 24.33 & 24.95 & 28.89 & 37.76 & 49.50 \\
\hline & \multicolumn{6}{|c|}{ (In billions of cubic meters per year) } \\
\hline \multicolumn{7}{|l|}{ Natural gas production and exports } \\
\hline Natural gas production & 35.9 & 45.0 & 43.4 & 44.4 & 45.4 & 46.8 \\
\hline LNG exports & 7.1 & 7.5 & 7.1 & 7.4 & 7.4 & 7.5 \\
\hline NGL exports & 12.3 & 11.5 & 11.9 & 13.1 & 13.0 & 13.4 \\
\hline & \multicolumn{6}{|c|}{ (Annual percentage changes) } \\
\hline \multicolumn{7}{|l|}{ National income and prices } \\
\hline Real GDP (at factor cost) & 12.4 & 1.7 & 2.6 & 11.6 & 7.8 & 7.3 \\
\hline Crude oil, condensates and natural gas & 13.1 & 0.0 & -7.6 & 13.6 & 2.9 & 7.0 \\
\hline Nonhydrocarbon sectors $2 /$ & 12.0 & 2.5 & 7.7 & 10.8 & 9.9 & 7.3 \\
\hline GDP deflator & 13.8 & -3.1 & 4.6 & 5.7 & 9.2 & 14.5 \\
\hline Consumer prices & 1.4 & 2.8 & 2.9 & 3.1 & 4.6 & 6.0 \\
\hline Volume of imports & 16.2 & 12.1 & 9.6 & 8.7 & 10.1 & 15.0 \\
\hline Volume of non-oil exports & -7.2 & 30.0 & 9.2 & 26.2 & 18.4 & 7.2 \\
\hline & \multicolumn{6}{|c|}{ (In percent of GDP) } \\
\hline \multicolumn{7}{|l|}{ Investment and saving } \\
\hline Gross domestic investment & 23.2 & 24.7 & 24.0 & 23.4 & 22.1 & 20.4 \\
\hline Government & 4.3 & 5.2 & 4.5 & 4.9 & 4.1 & 3.4 \\
\hline Nongovernment & 18.8 & 19.4 & 19.5 & 18.5 & 18.1 & 17.0 \\
\hline National saving & 40.9 & 35.3 & 28.6 & 31.9 & 34.4 & 39.6 \\
\hline Government & 17.5 & 7.0 & 15.5 & 18.3 & 21.9 & 26.3 \\
\hline Nongovernment & 23.4 & 28.3 & 13.1 & 13.6 & 12.5 & 13.3 \\
\hline Saving less investment & 17.7 & 10.7 & 4.6 & 8.5 & 12.3 & 19.2 \\
\hline \multicolumn{7}{|l|}{ Consolidated government finances } \\
\hline Revenue & 44.3 & 37.1 & 41.8 & 41.1 & 42.7 & 43.6 \\
\hline Hydrocarbon & 32.8 & 26.6 & 32.6 & 32.8 & 33.0 & 33.8 \\
\hline Nonhydrocarbon & 11.5 & 10.5 & 9.1 & 8.4 & 9.7 & 9.8 \\
\hline Of which: Investment income & 5.8 & 4.5 & 3.2 & 3.0 & 3.6 & 4.7 \\
\hline Expenditure & 31.8 & 37.4 & 31.5 & 28.2 & 24.4 & 21.0 \\
\hline \multicolumn{7}{|l|}{ Of which } \\
\hline Current & 26.8 & 30.0 & 26.3 & 22.8 & 20.8 & 17.3 \\
\hline Development 3/ & 4.6 & 7.0 & 4.8 & 4.9 & 3.5 & 3.5 \\
\hline Current balance & 17.5 & 7.0 & 15.5 & 18.3 & 21.9 & 26.3 \\
\hline Overall balance & 12.4 & -0.4 & 10.3 & 13.0 & 18.3 & 22.6 \\
\hline Overall balance (excluding investment income) & 6.6 & -4.9 & 7.1 & 9.9 & 14.7 & 17.9 \\
\hline (Excluding hydrocarbon revenue) & -26.2 & -31.5 & -25.5 & -22.8 & -18.3 & -15.9 \\
\hline Financing & -12.4 & 0.4 & -10.3 & -13.0 & -18.3 & -22.6 \\
\hline Domestic banks & -4.1 & -0.2 & -3.1 & -0.7 & -0.5 & 0.1 \\
\hline Other & -8.4 & 0.6 & -7.2 & -12.3 & -17.8 & -22.7 \\
\hline Government debt 4/ & 4.6 & 4.0 & 5.3 & 6.6 & 8.4 & 6.9 \\
\hline
\end{tabular}


Table 1. U. A. E. Selected Economic Indicators, 2000-05

\begin{tabular}{|c|c|c|c|c|c|c|}
\hline & 2000 & 2001 & 2002 & 2003 & $\frac{\text { Prel. }}{2004}$ & $\frac{\text { Proj. }}{2005}$ \\
\hline & \multicolumn{6}{|c|}{ (Changes in percent of initial stock of M2) } \\
\hline \multicolumn{7}{|l|}{ Money and credit } \\
\hline Broad money (M2) & 15.3 & 15.3 & 15.6 & 16.1 & 23.2 & 15.0 \\
\hline Foreign assets (net) & 20.2 & 8.7 & 20.1 & 1.9 & 13.6 & 11.1 \\
\hline Domestic assets & -4.9 & 6.5 & -4.5 & 14.2 & 9.6 & 3.9 \\
\hline \multicolumn{7}{|l|}{ Of which } \\
\hline Claims on government (net) & -9.6 & -0.4 & -5.8 & -1.3 & -0.9 & 0.1 \\
\hline Claims on public sector enterprises & 0.2 & -0.4 & 1.3 & 3.5 & 0.5 & 0.1 \\
\hline Claims on private sector & 9.0 & 8.5 & 10.4 & 11.9 & 21.3 & 15.2 \\
\hline & \multicolumn{6}{|c|}{ (In percent per annum) } \\
\hline \multicolumn{7}{|l|}{ Average interest rates } \\
\hline Dirham (three-month interbank) & 6.53 & 3.46 & 1.86 & 1.29 & 1.94 & $\ldots$ \\
\hline Lending rate & 9.60 & 7.82 & 6.82 & 5.81 & 5.87 & $\ldots$ \\
\hline & \multicolumn{6}{|c|}{ (In billions of U.S. dollars) } \\
\hline \multicolumn{7}{|l|}{ External sector } \\
\hline Exports & 49.6 & 47.5 & 52.5 & 67.3 & 82.3 & 103.4 \\
\hline Crude oil & 21.7 & 17.6 & 16.6 & 22.1 & 29.6 & 41.5 \\
\hline Petroleum products & 1.7 & 2.1 & 3.6 & 3.8 & 3.7 & 5.0 \\
\hline Gas & 3.7 & 3.3 & 3.3 & 3.9 & 4.7 & 6.9 \\
\hline Nonhydrocarbon exports & 7.5 & 8.5 & 10.6 & 14.1 & 16.6 & 18.3 \\
\hline Re-exports & 15.0 & 16.0 & 18.3 & 23.4 & 27.7 & 31.7 \\
\hline Imports, f.o.b. & -30.8 & -33.5 & -37.5 & -45.8 & -54.2 & -63.0 \\
\hline Trade balance & 18.8 & 14.0 & 14.9 & 21.5 & 28.1 & 40.4 \\
\hline Services (net) & -6.4 & -6.2 & -7.7 & -9.1 & -10.8 & -13.0 \\
\hline Income (net) & 3.8 & 2.9 & 0.8 & -0.1 & 0.1 & 3.6 \\
\hline Transfers (net) & -4.0 & -4.2 & -4.4 & -4.7 & -5.1 & -6.5 \\
\hline Private & -3.7 & -3.9 & -4.1 & -4.4 & -4.6 & -6.1 \\
\hline Official & -0.3 & -0.3 & -0.3 & -0.3 & -0.4 & -0.4 \\
\hline Current account balance & 12.2 & 6.5 & 3.8 & 7.7 & 12.3 & 24.5 \\
\hline (In percent of GDP) & 17.2 & 9.4 & 5.0 & 8.7 & 11.8 & 19.2 \\
\hline Overall balance & 2.8 & 0.5 & 1.1 & -0.2 & 3.5 & 2.9 \\
\hline Central Bank reserves & 13.8 & 14.3 & 15.3 & 15.1 & 18.6 & 21.5 \\
\hline In months of imports & 4.9 & 4.6 & 4.0 & 3.3 & 3.5 & 3.9 \\
\hline As percent of reserve money & 250.2 & 242.8 & 223.5 & 181.8 & 176.7 & 182.3 \\
\hline As percent of short-term debt $5 /$ & 168.6 & 162.4 & 164.6 & 164.2 & 212.0 & 241.8 \\
\hline Total external debt $6 /$ & 18.2 & 19.4 & 16.7 & 16.5 & 15.8 & 16.0 \\
\hline (In percent of GDP) & 25.8 & 27.9 & 22.3 & 18.7 & 15.1 & 12.5 \\
\hline \multicolumn{7}{|l|}{ Memorandum item } \\
\hline Dirhams/U.S. dollar (end of period) & 3.6725 & 3.6725 & 3.6725 & 3.6725 & 3.6725 & 3.6725 \\
\hline
\end{tabular}

Sources: U.A.E. authorities; Bank for International Settlements (BIS); Organization for Economic Cooperation and Development (OECD); and IMF staff estimates.

1/ Crude oil output includes condensates, which are not subject to OPEC quotas.

2/ Includes refined products and liquid gas.

3/ Includes net loans and equity.

4/ Due to domestic banks; no official external debt is reported.

5/ Debt due within one year, from BIS/OECD statistics.

6/ Central Bank and commercial bank foreign liabilities, plus private nonbanks (BIS source). 
Table 2. U.A.E.: Balance of Payments, 2000-05

(In billions of U.S. dollars)

\begin{tabular}{|c|c|c|c|c|c|c|}
\hline & 2000 & 2001 & 2002 & 2003 & $\frac{\text { Est. }}{2004}$ & $\frac{\text { Proj. }}{2005}$ \\
\hline Trade balance & 18.8 & 14.0 & 14.9 & 21.5 & 28.1 & 40.4 \\
\hline Exports & 49.6 & 47.5 & 52.5 & 67.3 & 82.3 & 103.4 \\
\hline Oil and products & 23.4 & 19.7 & 20.3 & 25.8 & 33.3 & 46.5 \\
\hline Crude oil \& condensates & 21.7 & 17.6 & 16.6 & 22.1 & 29.6 & 41.5 \\
\hline Petroleum products $1 /$ & 1.7 & 2.1 & 3.6 & 3.8 & 3.7 & 5.0 \\
\hline Gas & 3.7 & 3.3 & 3.3 & 3.9 & 4.7 & 6.9 \\
\hline Nonhydrocarbon & 7.5 & 8.5 & 10.6 & 14.1 & 16.6 & 18.3 \\
\hline Exports by Emirates & 2.0 & 2.0 & 2.4 & 2.9 & 3.5 & 3.9 \\
\hline Free zone exports & 5.5 & 6.4 & 8.3 & 11.3 & 13.1 & 14.5 \\
\hline Re-exports, Of which:2/ & 15.0 & 16.0 & 18.3 & 23.4 & 27.7 & 31.7 \\
\hline Nonmonetary gold & 1.9 & 1.9 & 1.9 & 2.0 & 2.3 & 2.3 \\
\hline Imports (f.o.b.) & -30.8 & -33.5 & -37.5 & -45.8 & -54.2 & -63.0 \\
\hline Imports by Emirates & -25.9 & -26.8 & -29.4 & -35.4 & -42.1 & -48.7 \\
\hline Free zones & -4.9 & -6.7 & -8.1 & -10.4 & -12.1 & -14.3 \\
\hline Income, net & 3.8 & 2.9 & 0.8 & -0.1 & 0.1 & 3.6 \\
\hline Banking system & 1.6 & 1.0 & 0.5 & 0.4 & 0.6 & 1.5 \\
\hline Private nonbanks & 0.4 & 0.3 & 0.1 & 0.1 & 0.1 & 0.1 \\
\hline Government & 4.0 & 3.0 & 2.2 & 1.9 & 3.8 & 5.7 \\
\hline Foreign partners - oil 3/ & -1.9 & -1.1 & -1.9 & -2.3 & -4.1 & -3.3 \\
\hline Foreign partners - gas $3 /$ & -0.3 & -0.2 & -0.2 & -0.2 & -0.4 & -0.4 \\
\hline Services, net & -6.4 & -6.2 & -7.7 & -9.1 & -10.8 & -13.0 \\
\hline Credits & 2.2 & 2.4 & 2.6 & 2.8 & 3.0 & 3.1 \\
\hline Travel & 1.1 & 1.2 & 1.3 & 1.4 & 1.6 & $\ldots$ \\
\hline Transport & 0.8 & 0.8 & 0.9 & 0.9 & 1.0 & $\ldots$ \\
\hline Government services & 0.3 & 0.4 & 0.4 & 0.4 & 0.5 & $\ldots$ \\
\hline Debits & -8.6 & -8.5 & -10.3 & -11.8 & -13.8 & -16.1 \\
\hline Travel & -3.0 & -3.0 & -3.7 & -4.0 & -4.5 & $\ldots$ \\
\hline Transport & -1.1 & -1.1 & -1.2 & -1.2 & -1.5 & $\ldots$ \\
\hline Government services & -0.3 & -0.3 & -0.4 & -0.4 & -0.4 & $\ldots$ \\
\hline Freight 4/ & -4.2 & -4.0 & -5.1 & -6.2 & -7.4 & $\ldots$ \\
\hline Transfers, net & -4.0 & -4.2 & -4.4 & -4.7 & -5.1 & -6.5 \\
\hline Private & -3.7 & -3.9 & -4.1 & -4.4 & -4.6 & -6.1 \\
\hline Official & -0.3 & -0.3 & -0.3 & -0.3 & -0.4 & -0.4 \\
\hline Current account balance & 12.2 & 6.5 & 3.8 & 7.7 & 12.3 & 24.5 \\
\hline (In percent of GDP) & 17.2 & 9.4 & 5.0 & 8.7 & 11.8 & 19.2 \\
\hline
\end{tabular}


Table 2. U.A.E.: Balance of Payments, 2000-05

(In billions of U.S. dollars)

\begin{tabular}{|c|c|c|c|c|c|c|}
\hline & 2000 & 2001 & 2002 & 2003 & $\frac{\text { Est. }}{2004}$ & $\frac{\text { Proj. }}{2005}$ \\
\hline Financial account balance & -9.7 & -4.1 & -7.3 & -7.8 & -10.9 & -22.4 \\
\hline Private capital & -3.8 & -3.9 & -1.9 & 3.9 & 7.7 & 6.6 \\
\hline Direct investment, net 4/ & -1.6 & 0.7 & 3.1 & 3.3 & 9.0 & 10.3 \\
\hline Outward & -2.1 & -0.4 & -0.4 & -1.0 & -1.0 & -1.0 \\
\hline Inward & 0.5 & 1.2 & 3.5 & 4.3 & 10.0 & 11.3 \\
\hline Portfolio securities & 0.0 & 0.0 & 0.2 & 0.0 & 2.0 & 1.5 \\
\hline Commercial banks & -3.2 & -2.5 & -6.9 & -1.1 & -5.5 & -4.4 \\
\hline Private nonbanks & 1.0 & -2.1 & 1.7 & 1.7 & 2.2 & -0.8 \\
\hline Official capital 5/ & -5.9 & -0.2 & -5.4 & -11.7 & -18.6 & -29.0 \\
\hline Errors and omissions & 0.4 & -2.0 & 4.7 & -0.1 & 2.1 & 0.8 \\
\hline (As percent of GDP) & 0.5 & -2.9 & 6.2 & -0.1 & 2.0 & 0.7 \\
\hline Overall balance & 2.8 & 0.5 & 1.1 & -0.2 & 3.5 & 2.9 \\
\hline Central Bank net foreign assets & -2.8 & -0.5 & -1.1 & 0.2 & -3.5 & -2.9 \\
\hline \multicolumn{7}{|l|}{ Memorandum items } \\
\hline Overall balance (as percent of GDP) & 4.0 & 0.7 & 1.4 & -0.2 & 3.4 & 2.3 \\
\hline Gross reserves of Central Bank & 13.8 & 14.3 & 15.3 & 15.1 & 18.6 & 21.5 \\
\hline (In months of imports) 6/ & 4.9 & 4.6 & 4.0 & 3.3 & 3.5 & 3.9 \\
\hline
\end{tabular}

Sources: U.A.E. authorities; and IMF staff estimates.

$1 /$ Includes fertilizers and lubricants.

2/ Not formally compiled; estimated at 40-50 percent of Emirates' imports.

3/ IMF staff estimates based on foreign partner share of oil and gas sector net profits.

4/ Estimated freight to adjust imports (cif basis in U.A.E. BOP accounts) to fob basis.

4/ UNCTAD direct investment estimates (World Investment Report).

5 / Includes changes in government external assets.

6/ Imports of goods and services in the next 12 months. 
Table 3. U.A.E.: Consolidated Government Finances, 2000-05

(In millions of U.A.E. dirhams)

\begin{tabular}{|c|c|c|c|c|c|c|}
\hline & 2000 & 2001 & 2002 & 2003 & $\frac{\text { Prel. }}{2004}$ & $\frac{\text { Proj. }}{2005}$ \\
\hline Total revenue & 89,691 & 78,440 & 66,086 & 84,079 & 110,574 & 148,514 \\
\hline Hydrocarbon & 59,978 & 51,648 & 40,926 & 56,898 & 73,322 & 102,590 \\
\hline Nonhydrocarbon & 29,713 & 26,792 & 25,160 & 27,181 & 37,252 & 45,924 \\
\hline Customs & 1,779 & 1,846 & 1,663 & 2,458 & 3,040 & 3,520 \\
\hline Profit transfers & 3,938 & 3,384 & 3,357 & 2,935 & 3,313 & 3,103 \\
\hline Income tax $1 /$ & 166 & 206 & 235 & 301 & 320 & 336 \\
\hline Fees and charges & 4,173 & 5,120 & 6,429 & 6,479 & 6,327 & 6,517 \\
\hline Investment income $2 /$ & 15,065 & 11,576 & 8,869 & 9,881 & 13,912 & 22,005 \\
\hline Other & 4,592 & 4,660 & 4,607 & 5,127 & 10,341 & 10,444 \\
\hline Total expenditure and grants & 82,542 & 95,558 & 86,616 & 91,563 & 93,384 & 98,376 \\
\hline Current expenditure & 69,441 & 76,732 & 72,426 & 74,255 & 79,536 & 81,095 \\
\hline Wages and salaries 3/ 4/ & 13,965 & 14,383 & 15,131 & 15,764 & 15,892 & 18,593 \\
\hline Goods and services 4/ & 21,287 & 22,491 & 23,745 & 26,519 & 27,172 & 27,987 \\
\hline Abu Dhabi "federal services" 5/ & 19,440 & 19,082 & 17,045 & 19,198 & 23,533 & 20,263 \\
\hline Subsidies and transfers & 14,237 & 20,128 & 16,108 & 11,372 & 12,346 & 12,716 \\
\hline Other & 513 & 648 & 397 & 1,402 & 593 & 1,534 \\
\hline Development expenditure & 11,230 & 13,358 & 12,470 & 16,028 & 15,515 & 16,136 \\
\hline Loans and equity (net) & 652 & 4,507 & 760 & 16 & $-2,308$ & 264 \\
\hline Domestic & 714 & 903 & 592 & -810 & 1,654 & 264 \\
\hline Foreign & -62 & 3,604 & 168 & 826 & $-3,962$ & 0 \\
\hline Foreign grants $6 /$ & 1,219 & 961 & 960 & 1,264 & 641 & 882 \\
\hline Abu Dhabi & 1,071 & 664 & 784 & 1,136 & 541 & 557 \\
\hline Federal & 148 & 297 & 176 & 128 & 100 & 325 \\
\hline Overall balance (consolidated) $7 /$ & 7,149 & $-17,118$ & $-20,530$ & $-7,484$ & 17,190 & 50,138 \\
\hline (In percent of GDP) & 2.8 & -6.7 & -7.5 & -2.3 & 4.5 & 10.7 \\
\hline \multicolumn{7}{|l|}{ Overall balance (including revenues from } \\
\hline $\begin{array}{l}\text { other government entities) } 8 \text { / } \\
\text { (In percent of GDP) }\end{array}$ & $\begin{array}{r}32,205 \\
12.4\end{array}$ & $\begin{array}{r}-905 \\
-0.4\end{array}$ & $\begin{array}{r}28,368 \\
10.3\end{array}$ & $\begin{array}{r}42,198 \\
13.0\end{array}$ & $\begin{array}{r}70,052 \\
18.3\end{array}$ & $\begin{array}{r}106,132 \\
22.6\end{array}$ \\
\hline Financing & $-32,205$ & 904 & $-28,368$ & $-42,198$ & $-70,052$ & $-106,132$ \\
\hline Resident banks, net 9/ & $-10,530$ & -538 & $-8,482$ & $-2,269$ & $-1,776$ & 330 \\
\hline Loans to government & $-2,854$ & $-1,595$ & 4,292 & 5,613 & 10,509 & 330 \\
\hline Government deposits & 7,676 & $-1,057$ & 12,774 & 7,882 & 12,285 & $\ldots$ \\
\hline Privatization receipts 10 / & $\ldots$ & 2,000 & $\ldots$ & 3,004 & $\ldots$ & $\ldots$ \\
\hline Official foreign assets $(-=$ increase $) 2 /$ & $-21,675$ & -558 & $-19,886$ & $-42,933$ & $-68,278$ & $-106,462$ \\
\hline \multicolumn{7}{|l|}{ Memorandum items } \\
\hline Nonhydrocarbon balance 11/ & $-52,829$ & $-68,766$ & $-61,456$ & $-64,382$ & $-56,132$ & $-52,452$ \\
\hline (In percent of GDP) & -20.4 & -26.9 & -22.3 & -19.8 & -14.7 & -11.2 \\
\hline (In percent of nonhydrocarbon GDP) & -30.8 & -38.4 & -30.7 & -28.0 & -22.0 & -18.4 \\
\hline Nonhydrocarbon balance (excluding investment income) & $-67,894$ & $-80,342$ & $-70,325$ & $-74,263$ & $-70,043$ & $-74,457$ \\
\hline (In percent of GDP) & -26.2 & -31.5 & -25.5 & -22.8 & -18.3 & -15.9 \\
\hline (In percent of non-hydrocarbon GDP) & -39.6 & -44.8 & -35.1 & -32.3 & -27.4 & -26.1 \\
\hline Hydrocarbon share of revenue & 74.1 & 71.7 & 78.1 & 79.7 & 77.2 & 77.5 \\
\hline Balance on pension fund operations 12 / & 1,970 & 1,274 & 1,653 & 3,593 & 3,511 & $\ldots$ \\
\hline
\end{tabular}

Sources: Federal government; Emirate finance departments; and IMF staff estimates.

$1 /$ Taxes on profit of foreign banks. Income taxes on gas companies are included under hydrocarbon revenues.

2/ Fund staff estimates.

3/ Excludes military wages and salaries, which are in goods and services.

4/ Water and electricity expenditure is allocated 25 percent to wages and salaries, and 75 percent goods and services.

5/ Largely military and internal security expenditures paid by Abu Dhabi but not in the federal accounts.

6/ Intragovernmental grants are netted out in the consolidated fiscal accounts.

7/ Consolidated accounts of the federal government, Abu Dhabi, Dubai and Sharjah.

8/ Fund staff estimates of ADNOC profits, other government entities and government domestic investments.

9/ From the monetary statistics.

10/ Abu Dhabi receipts from the sale of water and power assets.

11 / Non-hydrocarbon revenues less spending.

12/ Operations of the General Pension and Social Security Authority, which was established in 2000. 
Table 4. U.A.E.: Monetary Survey, 2000-05 1/

\begin{tabular}{|c|c|c|c|c|c|c|}
\hline End of Period & 2000 & 2001 & 2002 & 2003 & $\frac{\text { Prel. }}{2004}$ & $\frac{\text { Proj. }}{2005}$ \\
\hline & \multicolumn{6}{|c|}{ (In millions of U.A.E. dirhams) } \\
\hline Net foreign assets (NFA) & 88,111 & 99,179 & 128,654 & 131,848 & 158,664 & 185,536 \\
\hline Foreign assets & 141,112 & 149,991 & 166,960 & 167,255 & 194,927 & 222,156 \\
\hline Central Bank & 50,759 & 52,471 & 56,229 & 55,518 & 68,546 & 79,336 \\
\hline Commercial banks 2/ & 90,353 & 97,520 & 110,731 & 111,737 & 126,381 & 142,821 \\
\hline Foreign liabilities & 53,001 & 50,812 & 38,306 & 35,407 & 36,263 & 36,620 \\
\hline Central bank & 587 & 516 & 284 & 349 & 548 & 548 \\
\hline Commercial banks 2/ & 52,414 & 50,296 & 38,022 & 35,058 & 35,715 & 36,072 \\
\hline Domestic assets & 38,920 & 47,226 & 40,597 & 64,702 & 83,578 & 93,102 \\
\hline Claims on government (net) & $-18,228$ & $-18,766$ & $-27,248$ & $-29,517$ & $-31,293$ & $-30,963$ \\
\hline Claims & 11,800 & 10,205 & 14,497 & 20,110 & 30,619 & 30,949 \\
\hline Deposits & 30,028 & 28,971 & 41,745 & 49,627 & 61,912 & 61,912 \\
\hline Claims on public sector enterprises & 5,780 & 5,258 & 7,122 & 12,990 & 13,884 & 14,162 \\
\hline Claims on private non-banks & 123,313 & 134,132 & 149,352 & 169,469 & 211,407 & 248,318 \\
\hline Capital and reserves (-) & $-35,833$ & $-38,377$ & $-42,583$ & $-46,063$ & $-54,023$ & $-59,842$ \\
\hline Other assets (net) & $-36,112$ & $-35,021$ & $-46,046$ & $-42,177$ & $-56,397$ & $-78,572$ \\
\hline Central Bank & $-26,292$ & $-27,994$ & $-31,245$ & $-28,416$ & $-38,951$ & $-49,592$ \\
\hline Commercial banks 2/ & $-9,820$ & $-7,027$ & $-14,801$ & $-13,761$ & $-17,446$ & $-28,981$ \\
\hline Domestic liquidity (M2) & 127,031 & 146,409 & 169,251 & 196,550 & 242,242 & 278,639 \\
\hline Money & 34,067 & 39,464 & 47,054 & 58,262 & 80,818 & 91,698 \\
\hline Currency outside banks & 10,017 & 10,537 & 11,938 & 13,785 & 15,778 & 16,251 \\
\hline Dirham demand deposits & 24,050 & 28,927 & 35,116 & 44,477 & 65,040 & 75,446 \\
\hline Quasi-money & 92,964 & 106,945 & 122,197 & 138,288 & 161,424 & 186,941 \\
\hline Foreign currency deposits & 28,459 & 33,117 & 39,612 & 47,980 & 62,496 & 78,120 \\
\hline \multirow[t]{2}{*}{ Dirham time and savings deposits } & 64,505 & 73,828 & 82,585 & 90,308 & 98,928 & 108,821 \\
\hline & \multicolumn{6}{|c|}{ (Changes in percent of initial stock of M2, unless otherwise indicated) } \\
\hline \multicolumn{7}{|l|}{ Memorandum items } \\
\hline Net foreign assets & 20.2 & 8.7 & 20.1 & 1.9 & 13.6 & 11.1 \\
\hline Domestic assets & -4.9 & 6.5 & -4.5 & 14.2 & 9.6 & 3.9 \\
\hline Domestic credit (net) & -0.4 & 7.7 & 5.9 & 14.0 & 20.9 & 15.5 \\
\hline Claims on government (net) & -9.6 & -0.4 & -5.8 & -1.3 & -0.9 & 0.1 \\
\hline Claims on private sector & 9.0 & 8.5 & 10.4 & 11.9 & 21.3 & 15.2 \\
\hline Domestic liquidity (M2) & 15.3 & 15.3 & 15.6 & 16.1 & 23.2 & 15.0 \\
\hline Money (percent change) & 12.6 & 15.8 & 19.2 & 23.8 & 38.7 & 13.5 \\
\hline Quasi Money (percent change) & 11.9 & 11.0 & 10.4 & 9.5 & 11.8 & 10.5 \\
\hline Domestic credit (in AED millions, net) & 110,865 & 120,624 & 129,226 & 152,942 & 193,998 & 231,517 \\
\hline
\end{tabular}

Sources: Central Bank of the U.A.E., and IMF staff estimates.

$1 /$ Monetary survey is compiled in accordance with the residence principle.

2 / Including the restricted license bank. 
Table 5. U. A. E.: Selected Indicators of External Vulnerability, 2000-04

$2000 \quad 2001 \quad 2002 \quad 2003 \quad \frac{\text { Prel. }}{2004}$

External solvency indicators

REER (CPI-based, percent change, annual average)

Total external debt (in billions of U.S. dollars)

Short-term debt (BIS source; in billions of U.S dollars) 1/

Total external debt / GDP (percent)

Short-term debt/exports of goods and services (in percent)

$\begin{array}{rrrrr}5.9 & 6.5 & -0.5 & -7.8 & -5.1 \\ 18.2 & 19.4 & 16.7 & 16.5 & 15.8 \\ 8.2 & 8.8 & 9.3 & 9.2 & 8.8 \\ 25.8 & 27.9 & 22.3 & 18.7 & 15.1 \\ 15.9 & 17.6 & 16.9 & 13.1 & 10.3\end{array}$

Public sector solvency indicators (in percent)

Overall fiscal balance/GDP

Government domestic debt/GDP

Oil revenue/total revenue

Investment income/total revenue

Non-oil revenue (excl. investment income)/non-oil GDP

Non-oil balance/GDP

$\begin{array}{rrrrr}12.4 & -0.4 & 10.3 & 13.0 & 18.3 \\ 4.6 & 4.0 & 5.3 & 6.6 & 8.4 \\ 74.1 & 71.7 & 78.1 & 79.7 & 77.2 \\ 13.1 & 12.2 & 7.7 & 7.4 & 8.5 \\ 8.6 & 8.5 & 8.1 & 7.5 & 9.1 \\ -20.4 & -26.9 & -22.3 & -19.8 & -14.7\end{array}$

External liquidity indicators

Central bank foreign assets (in millions of U.S. dollars)

In months of imports of goods and services

As percent of M1

As percent of short-term external debt $1 /$

As percent of commercial banks foreign liabilities 2/

Commercial banks' NFA (in millions of U.S. dollars) 2/

Foreign assets

Foreign liabilities 2/

Crude oil exports/total exports (in percent)

$\begin{array}{rrrrr}13,821 & 14,288 & 15,311 & 15,117 & 18,610 \\ 4.9 & 4.6 & 4.0 & 3.3 & 3.5 \\ 149.0 & 133.0 & 119.5 & 95.3 & 84.6 \\ 168.6 & 162.4 & 164.6 & 164.2 & 212.0 \\ 96.8 & 104.3 & 147.9 & 158.4 & 191.4 \\ 10,331 & 12,859 & 19,798 & 20,879 & 24,688 \\ 24,603 & 26,554 & 30,151 & 30,425 & 34,413 \\ 14,272 & 13,695 & 10,353 & 9,546 & 9,725 \\ 43.8 & 37.0 & 31.7 & 32.8 & 36.0\end{array}$

Financial sector indicators

Foreign currency deposits/total deposits (in percent)

Net domestic assets (annual change in percent)

Private sector credit (annual change in percent)

Private credit/total assets of banks (in percent)

Interest rate spread against U.S. dollar (in basis points) 3/

$\begin{array}{rrrrr}24.3 & 24.4 & 25.2 & 26.3 & 27.6 \\ -12.1 & 21.3 & -14.0 & 59.4 & 29.2 \\ 8.7 & 8.8 & 11.3 & 13.5 & 24.7 \\ 46.5 & 47.4 & 47.3 & 48.2 & 48.8 \\ -0.12 & 0.18 & 0.02 & 0.11 & -0.07\end{array}$

Banking system indicators (in percent) $4 /$

Commercial banks' capital to assets ratio

Gross nonperforming loans/total lending

Return on assets

Return on equity

Average interest rate spread (in percentage points) 5/

\begin{tabular}{rrrrr}
19.5 & 19.8 & 19.0 & 18.6 & 16.9 \\
12.7 & 15.7 & 15.3 & 14.3 & 12.5 \\
1.8 & 1.9 & 1.9 & 1.9 & 2.1 \\
16.2 & 15.5 & 16.2 & 16.8 & 18.6 \\
3.7 & 4.7 & 5.6 & 5.1 & 4.9 \\
\hline
\end{tabular}

Sources: U.A.E. authorities; and IMF staff estimates.

$1 /$ On a remaining maturity basis.

$2 /$ Based on the residency principle.

3/ Spread between 3-month dirham interbank and 3-month U.S. dollar LIBOR.

4/ Updated during 2004 consultation.

5/ Spread between 3-month Dirham time deposits and local currency business loans. 
Table 6. U. A. E.: Medium-term Baseline Scenario, 2004-10

\begin{tabular}{|c|c|c|c|c|c|c|c|}
\hline & \multirow{2}{*}{$\frac{\text { Prel. }}{2004}$} & \multicolumn{6}{|c|}{ Projections } \\
\hline & & 2005 & 2006 & 2007 & 2008 & 2009 & 2010 \\
\hline \multirow{2}{*}{$\begin{array}{l}\text { Crude oil production (in mill. bbl/day) 1/ } \\
\text { Of which: Condensates }\end{array}$} & 2.66 & 2.80 & 2.87 & 2.94 & 3.02 & 3.09 & 3.17 \\
\hline & 0.33 & 0.40 & 0.41 & 0.42 & 0.43 & 0.44 & 0.45 \\
\hline \multirow[t]{2}{*}{ Average U.A.E. oil export price (In US\$/barrel) 2/ } & 36.30 & 48.75 & 48.00 & 45.75 & 44.50 & 43.75 & 43.25 \\
\hline & \multicolumn{7}{|c|}{ (in billions of cubic meters per year) } \\
\hline \multicolumn{8}{|l|}{ Natural gas production and exports } \\
\hline Natural gas production & 45.4 & 46.8 & 48.2 & 49.6 & 51.1 & 52.6 & 54.2 \\
\hline LNG exports & 7.4 & 7.5 & 7.6 & 7.7 & 7.9 & 8.0 & 8.1 \\
\hline \multirow[t]{2}{*}{ NGL exports } & 13.0 & 13.4 & 13.8 & 14.2 & 14.6 & 15.0 & 15.5 \\
\hline & \multicolumn{7}{|c|}{ (Percentage change; except as noted) } \\
\hline Nominal GDP (in billions of U.A.E. dirhams) & 382.7 & 469.3 & 492.5 & 507.9 & 527.9 & 551.1 & 576.9 \\
\hline Real GDP (at factor cost) & 7.8 & 7.3 & 5.1 & 4.6 & 4.3 & 4.3 & 4.3 \\
\hline Crude oil and natural gas 3 / & 2.9 & 7.0 & 2.5 & 2.5 & 2.5 & 2.5 & 2.5 \\
\hline Nonhydrocarbon 4/ & 9.9 & 7.3 & 6.2 & 5.4 & 5.0 & 4.9 & 4.9 \\
\hline \multirow[t]{2}{*}{ Consumer prices } & 4.6 & 6.0 & 4.5 & 3.9 & 3.3 & 2.6 & 2.6 \\
\hline & \multicolumn{7}{|c|}{ (In percent of GDP) } \\
\hline National saving & 34.4 & 39.6 & 39.3 & 37.6 & 37.0 & 36.2 & 36.1 \\
\hline Government & 21.9 & 26.3 & 26.9 & 26.4 & 25.9 & 25.6 & 25.4 \\
\hline Nongovernment & 12.5 & 13.3 & 12.3 & 11.2 & 11.1 & 10.6 & 10.7 \\
\hline Gross domestic investment & 22.1 & 20.4 & 20.4 & 20.5 & 21.0 & 21.0 & 20.9 \\
\hline Government & 4.1 & 3.4 & 3.4 & 3.4 & 3.4 & 3.4 & 3.4 \\
\hline \multirow[t]{2}{*}{ Nongovernment } & 18.1 & 17.0 & 16.9 & 17.0 & 17.6 & 17.6 & 17.5 \\
\hline & \multicolumn{7}{|c|}{ (In billions of U.A.E. dirhams) } \\
\hline \multicolumn{8}{|l|}{ Consolidated fiscal accounts } \\
\hline Revenue & 163.4 & 204.5 & 215.7 & 219.1 & 224.0 & 230.6 & 238.2 \\
\hline Hydrocarbon & 126.2 & 158.6 & 159.7 & 155.9 & 155.2 & 156.1 & 157.8 \\
\hline Nonhydrocarbon & 37.3 & 45.9 & 56.0 & 63.2 & 68.8 & 74.5 & 80.4 \\
\hline Of which: Investment income 5/ & 13.9 & 22.0 & 31.5 & 38.1 & 43.1 & 48.1 & 53.4 \\
\hline Expenditure, $\mathrm{O} f$ which: & 93.4 & 98.4 & 101.1 & 103.9 & 106.7 & 109.6 & 112.6 \\
\hline Current & 79.5 & 81.1 & 83.1 & 85.2 & 87.3 & 89.5 & 91.7 \\
\hline Development & 15.5 & 16.1 & 16.8 & 17.5 & 18.2 & 18.9 & 19.6 \\
\hline Overall balance & 70.1 & 106.1 & 114.7 & 115.3 & 117.3 & 121.0 & 125.6 \\
\hline (In percent of GDP) & 18.3 & 22.6 & 23.3 & 22.7 & 22.2 & 22.0 & 21.8 \\
\hline Excluding hydrcarbon revenue & -70.0 & -74.5 & -76.5 & -78.7 & -81.0 & -83.2 & -85.6 \\
\hline (In percent of GDP) & -18.3 & -15.9 & -15.5 & -15.5 & -15.3 & -15.1 & -14.8 \\
\hline \multirow[t]{2}{*}{ (In percent of nonhydrocarbon GDP) } & -27.4 & -26.1 & -24.9 & -24.1 & -23.3 & -22.5 & -21.8 \\
\hline & \multicolumn{7}{|c|}{ (In billions of U.S. dollars) } \\
\hline \multicolumn{8}{|l|}{ External accounts } \\
\hline Exports & 82.3 & 103.4 & 105.1 & 107.5 & 111.4 & 116.1 & 121.3 \\
\hline Of which: Crude oil and products & 33.3 & 46.5 & 46.8 & 45.6 & 45.3 & 45.6 & 46.1 \\
\hline Imports, f.o.b. & -54.2 & -63.0 & -66.5 & -71.1 & -76.1 & -81.4 & -87.0 \\
\hline Services (net) & -10.8 & -13.0 & -13.7 & -14.6 & -15.7 & -16.8 & -18.1 \\
\hline Investment income (net) $5 /$ & 0.1 & 3.6 & 7.4 & 9.4 & 11.0 & 12.5 & 14.2 \\
\hline Transfers (net) & -5.1 & -6.5 & -7.0 & -7.5 & -7.5 & -7.5 & -6.5 \\
\hline Current account balance & 12.3 & 24.5 & 25.4 & 23.7 & 23.0 & 22.8 & 23.8 \\
\hline (In percent of GDP) & 11.8 & 19.2 & 18.9 & 17.1 & 16.0 & 15.2 & 15.2 \\
\hline Central Bank reserves & 18.6 & 21.5 & 24.1 & 26.4 & 28.8 & 31.0 & 33.4 \\
\hline (In months of imports) & 3.5 & 3.9 & 4.1 & 4.2 & 4.2 & 4.4 & 4.6 \\
\hline External debt 6/ & 15.8 & 16.0 & 16.2 & 16.5 & 16.7 & 17.0 & 18.1 \\
\hline
\end{tabular}

Sources: U.A.E. authorities; and IMF staff estimates and projections.

1/ Includes condensates, which are not subject to the OPEC quota.

2/ Based on March 2004 WEO oil price projections.

3/ Crude oil output includes condensates. A large increase in condensates is planned for 2005 .

4/ Includes refined oil products and liquid gas.

5/ Due to domestic banks; no official external debt is reported.

6/ Includes liabilities of resident banks. 


\section{United Arab Emirates: Fund Relations}

(As of April 30, 2005)

I. Membership Status: Joined 9/22/72; accepted Article VIII status in February 1974.

II. General Resources Account:

Quota

Fund holdings of currency

Reserve position in Fund

III. SDR Department:

Net cumulative allocation

Holdings
SDR Million

611.70

435.53

176.78

SDR Million

38.74

4.35

None

IV. Outstanding Purchases and Loans:

V. Financial Arrangements:

VI. Projected Payments to Fund:

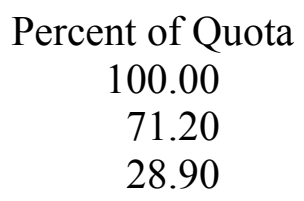

71.20

28.90

Percent of Allocation

100.00

11.22

(SDR million; based on existing use of resources and present holdings of SDRs):

\begin{tabular}{lccccc}
\hline & \multicolumn{5}{c}{ Forthcoming } \\
& 2005 & 2006 & 2007 & 2008 & 2009 \\
\hline & & & & & \\
Principal charges/ & & & & & \\
$\quad$ Interest & 0.63 & 0.86 & 0.86 & 0.86 & 0.86 \\
$\quad$ Total & 0.63 & 0.86 & 0.86 & 0.86 & 0.86 \\
\hline
\end{tabular}

VII. Implementation of HIPC Initiative:

Not Applicable

\section{Exchange Rate Arrangement:}

The U.A.E. dirham was officially pegged to the SDR at the rate of AED $4.76190=$ SDR 1 from November 1980 to February 2002 - albeit, in practice, it was pegged to the dollar at a fixed parity. Since then, in line with commitments agreed on with other GCC countries toward the adoption of a common currency in 2010, the U.A.E. dirham has become officially pegged to the U.S. dollar. The mid-point between the official buying and selling rates for the dirham has been AED 3.6725=\$1 since November 1997 . 


\section{Exchange System}

The U.A.E.'s exchange system is free of restrictions on the making of payments and transfer for current international transactions, except for those restrictions that are yet to be notified to the Fund, by the authorities, in accordance with Executive Board Decision No. 144 (52/51). ${ }^{19}$

\section{Article IV Consultation}

The U.A.E. is on the standard 12-month consultation cycle. The last Article IV consultation discussions were held during February 17-March 4, 2004, and the staff report (IMF Country Report No.: 04/175 as posted in www.imf.org) and the Statistical Appendix (IMF Country Report No.: 04/174 as posted in www.imf.org) were considered by the Executive Board on May 28, 2004.

\section{Technical Assistance:}

\begin{tabular}{|c|c|c|}
\hline STA & Multisector & June 1993 \\
\hline FAD & Government financial management & June 1994 \\
\hline STA & Data collection and balance of payments & December 1995 \\
\hline STA & $\begin{array}{l}\text { Terms of reference and arrangements for } \\
\text { resident advisor in balance of payments }\end{array}$ & April 1997 \\
\hline STA & International reserves & May 1998 \\
\hline FAD & Public Expenditure Management & November 2000 \\
\hline FAD & Public Expenditure Management follow up & May 2003 \\
\hline STA & Multisector & December 2003 \\
\hline MFD & $\begin{array}{l}\text { Anti-Money Laundering/Combating } \\
\text { terrorist financing }\end{array}$ & March 2004 \\
\hline TA & Coordinated Portfolio Investment Survey & April 2004 \\
\hline
\end{tabular}

\section{Resident Representative: None.}

\footnotetext{
${ }^{19}$ The staff has sought clarification with the authorities whether they intend to notify under Executive Board Decision 144, measures taken in line with U.N. Security Council resolutions against terrorist financing (e.g., 1373), as these measures may give rise to exchange restrictions subject to Fund jurisdiction. The staff is also awaiting a notification from the authorities regarding whether restrictions on transactions with the Federal Republic of Yugoslavia (Serbia and Montenegro) pursuant to resolutions of the U.N. Security Council have been lifted.
} 


\section{United Arab Emirates: Relations with the World Bank Group}

As of May 19, 2005

- A Framework Agreement for annual technical cooperation programs was signed in 1994. It replaced the previous arrangement based on ad-hoc requests. The first Annual Work Program of 1995-96 included two main studies-a Comprehensive Health Assessment Study and a study to restructure Government Information Authority, the Government's computer center.

- $\quad$ Education sector, recruitment and welfare. Three projects in these areas were completed in 2000: Public Expenditure Review for the Education Sector; Review and Assessment of Recruitment Procedures for the Federal government; and Analysis of Distribution of Welfare in Abu Dhabi.

- $\quad$ Environmental Assessment. In August of 2003, the U.A.E showed interest in Bank support for a U.A.E-wide environmental assessment. A Bank needs-assessment mission visited Dubai early this year to develop the project concept.

- Investment Climate. In response to a request from the advisor to the Crown Prince of Ras Al Khaimah (RAK) for assistance in the area of Foreign Investment and Economic Development, a World Bank mission visited the Emirate late February 2004. Following discussion in RAK, the Bank team prepared TORs for the first of a four-phase program, and agreement was signed in late March. The second phase consisting in an assessment of the investment climate in RAK is being followed by an Investors' Promotion Conference in May 27-28, 2005 intended to increase awareness that this Emirate could quickly develop as a serious contender for investment destination. 


\section{United Arab Emirates: Statistical Issues}

1. There are numerous shortcomings in the U.A.E.'s economic and financial data. These reflect inadequate compilation techniques, infrequent data reporting, shortage of trained staff, insufficient resources assigned to data gathering, and poor information flow between Federal and Emirate governments and public sector entities. ${ }^{20}$ As a result, provision of data to the Fund between missions remains poor, except for monetary and fragmentary trade statistics. In addition, the low frequency of official statistics - most data are produced only on an annual basis - also hampers this provision. This appendix reviews the overall status of statistical issues by sector. Data on core economic indicators are found in the accompanying Table.

2. The U.A.E. has received several STA technical assistance missions over the past decade. The 2003 STA multisector statistics mission concluded that, while the methodology used to compile macroeconomic statistics is generally appropriate, in most sectors serious deficiencies exist. ${ }^{21}$ These are attributable to the lack of sufficient and regular data sources in the real sector; inadequate coordination among the data compiling agencies; and constraints from distribution of personnel and financial resources between the Federal government and the largest Emirates. In response to the authorities' interest in participating in the General Data Dissemination System (GDDS), the 2003 mission worked with U.A.E. officials to prepare draft GDDS metadata, which require finalization by the authorities. This step, together with nomination of a GDDS coordinator, and agreement by the authorities to use the GDDS as a framework for the development of the country's statistical system, would complete the criteria needed for the U.A.E. to become a GDDS participant. The U.A.E. hosted a GDDS workshop in Abu Dhabi during February 27-March 9, 2005. The authorities have indicated that a GDDS country coordinator will be appointed shortly.

\section{Real sector}

3. The Ministry of Economy and Planning (MOEP) compiles an annual CPI, which is disseminated three months after the end of the reference year. A number of shortcomings exist with respect to the methodology of the CPI, including: (i) outdated weights that are not representative for all geographic regions; (ii) no imputations are made for missing price data; (iii) replacement product prices are not adjusted for changes in quality; and (iv) base price and expenditure weights refer to different periods. Because of the lack of resources, the MOPE has no short-term plans to compile the CPI monthly. The MOEP does not currently compile a producer price index, an import price or an export price index, which is a significant deficiency, given the role of the oil sector in the U.A.E.

4. The MOEP compiles and disseminates annual estimates of gross domestic product (GDP) by production and expenditure approach in current and constant 1995 prices. The national accounts compilation system suffers from a number of deficiencies. There is no comprehensive data collection program to provide a basis for compiling national accounts aggregates. Instead, the existing system relies heavily on administrative and other ad-hoc data collected by Federal and

\footnotetext{
${ }^{20}$ Key members of the remaining staff (all expatriates) are nearing retirement; questions of training and replacements are not known to have been addressed.
}

${ }^{21}$ United Arab Emirates: Report of the Multisector Statistics/GDDS mission, December 2003. 
Emirate institutions. The data collected are mostly quantity data. The last benchmark data available for compiling output are from 1995, while for intermediate consumption from 1980. Basic data remain inadequate for manufacturing, construction, wholesale and retail trade, and most of the other service sectors. In particular, real value added for petrochemicals, which accounts for nearly half of total manufacturing value added, is not estimated according to the 1993 SNA methodology. Instead nominal value added is deflated by an estimated import price deflator, as is done with real hydrocarbon value added. This methodology yields a purchasing power measure of petrochemical output, which may result in under or overestimation of volume growth, depending on changes in crude oil prices. Despite their importance in total GDP, oil and gas sector data are received with a lag from the Abu Dhabi National Oil Company (ADNOC). No national household budget survey has ever been conducted. In addition to the inadequate sources, the statistical techniques used in compiling GDP by production and expenditure approach are not sound.

5. Although labor statistics collected in the census are broadly in line with ILO recommendations, there are notable divergences from ILO definitions, including inconsistency of some concepts and irregular and incomplete updating of the census data. Lack of regular household surveys prevents compilation of annual data on basic national labor force statistics such as wages, unemployment, labor force and employment. Wage statistics are, for example, available only for a small proportion of government employees.

\section{Fiscal sector}

6. Principal deficiencies can be attributed to both the lack of coordination among the Emirates and Federal government, and the low frequency in reporting of government financial operations. The Ministry of Finance and Industry (MOFI) compiles data for the Federal government only. Separate fiscal data on the Federal government and three Emirates (Abu Dhabi, Dubai, and Sharjah), which are provided to the annual Article IV consultations, are employed by Fund staff to provide a consolidated fiscal account for the U.A.E. An annual, "consolidated" fiscal statement is published in the central bank's Statistical Bulletin, which is different from the Fund staff presentation. In particular, investment income from government assets is not included in the fiscal account. In addition, key information, such as investment income, and expenditure under the control of the respective Rulers' Offices and municipalities, remains off-budget in some Emirates, hindering comparison of fiscal developments across the Emirates and the Federal government. International standards of economic classification of expenditure and revenue are not fully followed.

7. The last data reported to STA for publication in the Government Finance Statistics Yearbook were for 1999 and covered only the Federal government. No financing information is provided by either the Federal authorities or any of the Emirates. No sub-annual data are reported for publication to the IMF's International Financial Statistics (IFS). Information on pension fund activities 
administered by the authorities through the Federal-level General Pension and Social Security Authority (GPSSA) has been available since the 2002 consultation mission. ${ }^{22}$

\section{Monetary sector}

8. Until recently, the principal issues in monetary statistics were limited to the classification and sectorization of loans to the corporate, other resident, and non-resident sectors. Starting in mid2001, however, the Central Bank of the U.A.E. (CBU) change $d$ the method for compilation of banking data, such that deposits of U.A.E. residents booked in overseas branches/subsidiaries of locally incorporated banks were included in the measure of broad money, and cross border flows back to head offices were treated as "domestic." 23 The rationale behind this change, as explained by authorities, was their observation that almost all of the funds deposited in the overseas branches (to circumvent the reserve requirement) almost instantly found their way back into the domestic banking system. The compilation introduced in mid-2001 does not follow internationally accepted standards that are based on the residency principle. This compilation results in distortions in both net foreign assets of the banking system, which are needed for the balance of payments (BOP) accounts, and in measurement of broad money.

9. The 2003 STA multisector mission recommended that two sets of data be compiled - a core set for monetary reporting purposes and a supplementary data set that meets other objectives of the authorities. The multisector mission also recommended: that lags in monetary statistics, which are compiled monthly, but reported only quarterly, be reduced; full coverage of IMF accounts; further sectorization of financial transactions, in particular of various Emirate government accounts, that are currently reported in aggregate form; and further instrument classification of foreign securities and domestic investments into bonds, shares, and other equities. During the 2005 Article IV consultation mission the authorities indicated that they would look into publication of monetary data based on the residency principle.

\section{External sector}

10. Balance of payments (BOP) statistics suffer from a lack of primary data sources for most transactions. Only one CBU staff member is assigned to BOP compilation, and cooperation from other government agencies remains negligible. Many entries are estimates based on incomplete information and some important transactions, such as foreign direct investment (FDI), are not covered at all and only estimated by Fund's staff. There are major gaps in official and private transfers, oil companies' service payments, private and official investment income, and financial transactions for all sectors except banks. Progress in addressing these shortcomings continues to be hampered by staffing limitations in the compilation unit, inadequate inter-agency cooperation, and

\footnotetext{
${ }^{22}$ The GPSSA was established in January 1999 to provide pension and social security insurance benefits to all nationals working in the government and the private sectors (except Abu Dhabi government employees which have their own separate pension fund).

${ }^{23}$ The compilation initially introduced a bias into banking statistics, especially net foreign positions of commercial banks, of about AED 20 billion. BOP flows are also compromised, because these statistics are the source of banking flows in the BOP accounts.
} 
other restrictions on the $\mathrm{CBU}$ with respect to collection of data from individuals and institutions other than the banking. The U.A.E. does not report BOP data for publication in the IMF's IFS (with the exception of trade statistics, which have been irregular at best), or the Balance of Payments Statistics Yearbook (BOPSY).

11. The authorities publish and provide data to Fund missions on banking system foreign assets. Detailed information on central bank reserves and foreign currency liquidity is available. Commercial bank data are also reported. These data are disseminated on a monthly basis. Since 2000, the authorities in the Emirate of Abu Dhabi have provided to Fund staff, during Article IV consultation missions, approximate information on the Emirate's stock of external assets. In the 2004 and 2005 Article IV consultations, some details on the stock of official foreign assets of the government were provided.

12. The authorities do not compile or publish the International Investment Position (IIP) statement, despite ready availability of certain potential sources, such as banking and government statistics. Also, no data on FDI or private nonfinancial sector external assets and liabilities are collected - although, according to BIS statistics the U.A.E.'s external liabilities are relatively small.

\section{Socio-demographic statistics}

13. The U.A.E. follows the practice of many other countries, with the Central Statistics Department (CSD) of the MOEP taking the lead in conducting the population census and large surveys, while line ministries collect data through their administrative reporting systems. In the area of socio-demographic statistics, cooperation between the CSD and the various line ministries is effective, with the CSD using data from the other ministries in its annual statistical yearbook. The CSD also cooperates with the line ministries as needed and has provided methodological support for the various household surveys that have been conducted. As in other countries, a population and housing census is conducted every 10 years. Currently, the 2005 population census is in the preparation phase. At present, no data exist on measures of income distribution, poverty and access to basic services. 


\section{United Arab Emirates: Table of Common Indicators Required for Surveillance}

As of April 30, 2005

\begin{tabular}{|c|c|c|c|c|c|}
\hline & $\begin{array}{c}\text { Date of } \\
\text { Latest } \\
\text { Observation }\end{array}$ & $\begin{array}{c}\text { Date } \\
\text { Received }\end{array}$ & $\begin{array}{c}\text { Frequency } \\
\text { of } \\
\text { Data }^{4}\end{array}$ & $\begin{array}{l}\text { Frequency } \\
\text { of } \\
\text { Reporting }\end{array}$ & $\begin{array}{l}\text { Frequency } \\
\text { of } \\
\text { Publication }^{4}\end{array}$ \\
\hline Exchange Rates & $03 / 05$ & $04 / 05$ & M & M & M \\
\hline $\begin{array}{l}\text { International Reserve Assets and Reserve Liabilities } \\
\text { of the Monetary Authorities } 1\end{array}$ & $02 / 05$ & $03 / 05$ & M & M & M \\
\hline Reserve/Base Money & $12 / 04$ & $03 / 05$ & M & Q & Q \\
\hline Broad Money & $12 / 04$ & $03 / 05$ & M & Q & Q \\
\hline Central Bank Balance Sheet & $12 / 04$ & $03 / 05$ & M & Q & Q \\
\hline Consolidated Balance Sheet of the Banking System & $12 / 04$ & $03 / 05$ & M & Q & Q \\
\hline Interest Rates & $02 / 05$ & $03 / 05$ & M & Q & Q \\
\hline Consumer Price Index & 2004 & $3 / 05$ & A & A & A \\
\hline $\begin{array}{l}\text { Revenue, Expenditure, Balance and Composition of } \\
\text { Financing - General Government }{ }^{2}\end{array}$ & 2004 & $3 / 05$ & A & A & A \\
\hline $\begin{array}{l}\text { Revenue, Expenditure, Balance and Composition of } \\
\text { Financing- Central Government }\end{array}$ & 2004 & $3 / 05$ & A & A & A \\
\hline $\begin{array}{l}\text { Stocks of Central Government and Central } \\
\text { Government-Guaranteed Debt }\end{array}$ & 2004 & $3 / 05$ & A & A & A \\
\hline External Current Account Balance & 2004 & $3 / 05$ & A & A & A \\
\hline Exports and Imports of Goods and Services & 2004 & $3 / 05$ & M & A & A \\
\hline GDP/GNP & 2004 & $3 / 05$ & A & A & A \\
\hline Gross External Debt ${ }^{3}$ & $\ldots$ & $\ldots$ & $\ldots$ & $\ldots$ & $\ldots$ \\
\hline
\end{tabular}

${ }^{1}$ Gross International reserves of the Central Bank of the U.A.E.

${ }^{2}$ The general government consists of the Federal government and the three largest Emirates.

${ }^{3}$ The only reported international debt is the external liabilities of the banking system; these are available monthly.

${ }^{4}$ Daily (D), Weekly (W), Monthly (M), Quarterly (Q), Annually (A); NA: Not Available. 


\title{
Financial Sector Developments in the United Arab Emirates
}

\author{
Overview
}

1. This appendix examines trends of financial soundness indicators and recent developments in the banking system, securities and insurance markets, as well as in the payment system. In addition, developments in legal reforms, especially in the area of anti-money laundering, are covered. An update of the status of the follow up on the recommendations of the FSAP mission in 2001 is also assessed.

\section{Banking sector}

2. The banking sector in United Arab Emirates remains sound, bolstered by strong supervision, and a vibrant economy. The overall ratio of capital to risk-weighted assets (CAR) declined slightly to just under 17 percent from 19 percent in 2003 as banks increased their lending activity to profit from the economic expansion. Nonetheless, CAR remained well above the regulatory prudential norm of 10 percent. The official ratio of nonperforming loans (NPLs) to total loans remained somewhat high at 12.5 percent at end- $2004^{24}$, but a substantial increase in provisioning from 89 percent to 95 percent reduced the ratio of NPLs net of provisions to 3.6 percent. Banks reported that very few loans made recently had become nonperforming.

3. The banking sector activities expanded significantly during 2004. Deposits grew by 25 percent and lending, which was broad-based, grew by 25.5 percent. Bank profitability was enhanced by an increase mainly in interest income. Return on assets increased from 1.9 percent in 2003 to 2.1 percent in 2004, and return on equity increased from 16 percent to 20 percent.

\section{Banks in the U.A.E. do not appear to be exposed to currency risks, and interest rate} mismatches are small. While banks have a substantial long dollar positions, foreign exchange risks are limited by the government's credible commitment to the dollar peg and the limited non-dollar exposures. Longer-term fixed rate lending is not well-developed, limiting interest rate mismatches. Loan quality was enhanced by the CBU's implementation of risk-based supervision in 2002, which required banks to implement policies to mitigate credit, operational risks, and market risks.

5. Direct exposure to the booming real estate sector appeared to be minimal at end-2004. Banks' direct lending to the real estate as a share of total loans declined to 4.7 percent from 5.4 percent in 2003. Many real estate buyers make full payments in cash, and banks are generally reluctant to lend more than 70 percent of the value of the property. Lending to the construction sector grew by 18 percent during 2004, though as a percent of total lending it declined to 12.8 percent from 13.6 percent.

\footnotetext{
${ }^{24}$ Most of these loans are loans from the 1980s and early 1990s that remain in the books because of laws that do not allow for the writing off of loans as long as there is a chance that they will be repaid.
} 


\section{Monetary operations}

6. The certificates of deposits (CDs) continued to be the main monetary instrument used by the CBU to smooth out fluctuations in domestic liquidity. CDs are issued up to 18 months maturity, and the CBU can buy them back upon banks' request at a penalty rate. In 2004, the CBU increased its issuance of CDs by about 35 percent and the total stock of outstanding CDs was raised to about AED 16 billion. The CBU plans to extend CD maturities from the current 18 months to 60 months and to begin conducting repo operations based on these instruments.

\section{Securities}

7. The U.A.E. securities markets, the Abu Dhabi Securities Market (ADSM) and the Dubai Securities Market (DSM), have witnessed significant growth since their inceptions in 2001. Total market capitalization tripled to slightly over $\$ 82$ billion, while the cumulative value of the shares traded increased from $\$ 2$ billion in 2003 to $\$ 18$ billion in 2004 . The composite $\mathrm{P} / \mathrm{E}$ ratio for both the ADSM and DSM increased from 18 percent to 31 percent during the same period. The composite index of the two markets increased by 88 percent in 2004, after having increased by 32 percent in $2003 .^{25}$

8. The CBU has established clear guidelines on the exposure of banks to the securities market. These included: (i) a limit on bank's investment or lending for investment purposes in one company to less than 7 percent of own capital; and (ii) a limit on investment in commercial companies to less than 25 percent of own total capital.

9. The nonbank financial sector is expanding rapidly. As of end-2004, there were 218 nonbank financial institutions (NBFIs) operating in the U.A.E., including 7 investment companies, 7 finance companies, 110 moneychangers, 50 representative offices of foreign nonbank financial institutions, 32 monetary and financial intermediaries, such as brokers and 12 financial consultants. Of the 7 investment companies, 2 are branches of foreign banking groups, and the rest are independent companies and are not related to banking institutions.

\section{The CBU currently licenses, regulates, and supervises all nonbank financial}

institutions. Investment companies may conduct one or more of the following businesses: (i) open investment accounts and manage portfolios on behalf of individuals or companies; (ii) prepare feasibility studies for projects, market allotments, and traded companies; (iii) establish or manage investment trust funds; (iv) establish and/or manage other investment funds; and (v) underwrite capital of companies and syndicated loans.

\section{The Dubai International Financial Center (DIFC) began operations in}

September 2004. As of mid-March 2005, 11 financial institutions have been granted licenses to operate within the free zone. It is expected that this number will rise to about 50 by end-year. Considerable progress has been made with respect to the regulatory framework governing the DIFC, and an extensive set of laws has been created based on best international practices. By

25 As of mid-May, the composite index of the U.A.E. increased by over 75 . 
design, the DIFC is intended to be segregated from the financial center of the U.A.E. Banking operations are confined to institutional wholesale banking, with both deposit taking and lending in dirham prohibited.

\section{The DIFC is well established and has the potential to become a major international} financial center. The unique nature of the governance relationships involved, and the broad scope of its activities raise some concern about what risks are being created and what effects, if any, it may have on the monetary system of the U.A.E.. The authorities in the U.A.E. and DIFC agreed with the mission that it would be useful to have the operations and regulatory arrangements of the DIFC assessed by the Fund. Such a mission could potentially take place in late 2005 or early 2006.

\section{Progress continues on the drafting of a new banking law, company law, and law on} land ownership. There is still a need to rationalize and consolidate regulatory oversight, and the CBU and ESCA will need to coordinate closely to ensure that a comprehensive supervisory framework for the entire financial sector is in place. The regulatory and supervisory responsibilities for IPOs currently rest with the MOEP, but these should be transferred to ESCA as its capacity is strengthened. Considerations could also be given to transferring the supervision of investment companies and mutual funds from the CBU to ESCA. The authorities agreed with the mission's recommendation that they request a Reports on Standards and Codes (ROSC) mission, from the Fund, which was not conducted during the 2001 FSAP.

\section{Anti-money laundering}

\section{Major steps have been taken to put in place a strong legal framework to prevent} money laundering and financing of terrorist activities. In this connection, two laws were passed in 2004; one on dealing with financing of terrorism and the other addressing AML/CFT issues in the financial free zones. A law criminalizing money laundering that was adopted in 2002 has been widely cited as a model of best practices. Hawala dealers continue to voluntarily register and have been certified by the CBU. They are required to report on quarterly basis to the CBU their transaction records on transactions exceeding AED 2,000 (\$550). As of end-February 2005, the $\mathrm{CBU}$ has received 156 registration applications and 133 certificates have been issued.

\section{Islamic Banking}

15. Islamic banking has expanded in U.A.E. in recent years. In 2004 the number of Islamic banks doubled to 4 and their assets increased by 35 percent, versus 22 percent for total assets of the banking system. By end-2004, 13 percent of deposits and 10 percent of all bank assets were held by Islamic banks.

16. The central bank does not apply separate accounting standards to Islamic Banks. There are no explicit Sharia-compliant instruments with which the central bank could provide emergency liquidity support. However, the central bank has indicated that the 7-day overdraft facility available 
to all banks could be extended for more than 7 days and the penalty rate could be waived, if needed. ${ }^{26}$

\section{Insurance}

17. Improvements in insurance oversight are ongoing, but a comprehensive study of the insurance law and regulations has not been undertaken. An independent Supervision and Oversight Commission for supervision of insurance is being established and the relevant MOEP staff will move to this new authority once it is set up. A ministerial decree has been issued to allow foreign entry into the insurance market. The staff of the insurance division at the MOEP was increased from 10 to 17 in 2004.

18. Various amendments to the Insurance law have been proposed by the MOEP. Among these are: (i) new rules on risk allocation and financial solvency margins that bring technical specifications in line with international good practices; (ii) empowerment of the council of Ministers to establish a fund to guarantee contracts to policy holders and beneficiaries; and (iii) a possible removal of the ban on foreign equity participation in insurance companies by allowing up to 49 percent foreign ownership.

\section{Payment system}

19. The real time gross settlements interbank payment system has been expanded to all banks and telexes are no longer used for any transactions. The settlement system is still based on $\mathrm{T}+1$, but this will change to $\mathrm{T}+0$ when the image-based check clearing system is introduced in 2005 .

20. The CBU still grants overdrafts to banks, but these overdrafts are no longer made in excess of the reserve account balance. Overdrafts are repayable within six days and incur a penalty rate of 5 percent over the 3 month interbank rate. The authority to extend these overdrafts comes from a law that says the Central Bank can make loans and advances of 7 days without collateral.

\footnotetext{
${ }^{26}$ Under the overdraft facility, banks borrow against their reserves, including required reserves at a penalty rate for up to 7 days.
} 
United Arab Emirates: Financial Sector Indicators

$2000 \quad 2001 \quad 2002 \quad 2003 \quad 2004$

\section{Core indicators}

Deposit-taking institutions

Regulatory capital to risk-weighted assets

Regulatory Tier I capital to risk-weighted assets 1/

Nonperforming loans net of provisions to capital

Nonperforming loans to total gross loans

Return on assets

Return on equity

Interest margin to gross income

Noninterest expenses to gross income

Liquid assets to total assets

Liquid assets to short-term liabilities

Net open position in foreign exchange to capital

\section{Encouraged indicators}

Deposit-taking institutions

Capital to assets

Personnel expenses to noninterest expenses

Customer deposits to total (non-interbank) loans

Households

Household debt to GDP

Real estate loans to total loans

\section{Other indicators}

Loan loss reserves/non-performing loans

Deposits as percent of M2

Commercial banks loans to private sector as percent of total deposits

Number of commercial banks (end-of-period)

Number of banks with C.A.R. above 10 percent

Spread between 3-month interest rate on local

currency deposits and loans

Maximum spread between 3-month local currency

interbank rates for different banks (in basis points)

Foreign currency deposits as percent of M2

Foreign currency denominated lending/total lending

Total expenses to total revenues

Earning per employee (in millions of AED)
(In percent)

$\begin{array}{rrrrr}19.5 & 19.8 & 19.0 & 18.6 & 16.9 \\ 19.1 & 19.6 & 18.6 & 18.2 & 16.3 \\ 12.0 & 10.5 & 9.6 & 7.7 & 3.5 \\ 12.7 & 15.7 & 15.3 & 14.3 & 12.5 \\ 1.8 & 1.9 & 1.9 & 1.9 & 2.1 \\ 16.2 & 15.5 & 16.2 & 16.8 & 18.6 \\ 80.0 & 73.7 & 69.9 & 59.5 & 64.6 \\ 25.8 & 34.0 & 38.7 & 43.6 & 40.3 \\ 34.8 & 31.8 & 28.1 & 22.7 & 23.2 \\ -- & -- & -- & -- & -- \\ -- & -- & -- & -- & --\end{array}$

$\begin{array}{rrrrr}11.5 & 11.9 & 11.8 & 11.4 & 11.1 \\ 30.0 & 30.3 & 31.6 & 29.5 & 38.6 \\ 74 & 72 & 76 & 80 & 88 \\ 7.2 & 6.1 & 6.7 & 6.6 & 6.1 \\ 6.0 & 7.1 & 7.2 & 5.4 & 4.7\end{array}$

$\begin{array}{rrrrr}86.0 & 87 & 87.5 & 88.5 & 94.6 \\ 92.1 & 92.8 & 92.9 & 93.0 & 93.5\end{array}$

$\begin{array}{lllll}105.4 & 98.7 & 94.9 & 92.7 & 93.4\end{array}$

$\begin{array}{lllll}47 & 46 & 47 & 47 & 48\end{array}$

$\begin{array}{lllll}47 & 46 & 47 & 47 & 48\end{array}$

$\begin{array}{lllll}3.7 & 4.7 & 5.6 & 5.1 & 4.9\end{array}$

$\begin{array}{lllll}6.7 & 6.0 & 6.1 & 6.2 & 6.2\end{array}$

$\begin{array}{lllll}22.4 & 22.6 & 23.4 & 24.4 & 25.8\end{array}$

$\begin{array}{lllll}22.7 & 23.2 & 23.7 & 23.9 & 20.7\end{array}$

$\begin{array}{rrrrr}37.5 & 38.3 & 38.3 & 38.6 & 35.9 \\ 0.3 & 0.35 & 0.37 & 0.4 & 0.5\end{array}$

$\begin{array}{lllll}0.3 & 0.35 & 0.37 & 0.4 & 0.5\end{array}$

Source: Central Bank of the United Arab Emirates

1/ BIS Tier I plus Tier II Capital (net of deductions). 


\section{FSAP recommendations}

21. The ESCA substantially strengthened the supervision of securities by increasing its staff and providing those staff with training. Important steps have been taken to automate banking, securities transactions, and the payment system. Transparency has been strengthened by publishing some major laws and circulars on the internet and by maintaining a continuous two way dialogue with banks on supervision and laws and regulations.

\section{There has been progress on legal reforms, but this needs to keep pace with financial} sector development. The legal and regulatory framework remains fragmented and unclear in some areas, and could become problematic as the financial sector becomes more complex. The authorities are aware of this issue and are actively addressing it.

Table 2: Update of FSAP Recommendations

\section{Recommendation}

\section{Status}

\section{Banking Supervision}

(1) The supervision of groups containing both banks, insurance companies and securities firms should be enhanced by having regular contact between the CBU and insurance supervisor and securities regulator, and by ensuring that the $\mathrm{CBU}$ has assured access to the prudential returns of insurance companies in such groups. (Core Principle (CP) 1(6)).

(2) The new securities legislation requires the CBU to pre-approve holdings in listed banks exceeding 5 percent. Procedures for such pre-approvals should be established within the CBU. The principle of pre-approval should also be extended to non-listed banks. (CP 4)

(3) The CBU should issue guidelines or circulars requiring banks to have adequate policies and procedures for the identification, measurement and control of market risk (CP 12) and should introduce explicit requirements for banks to have a comprehensive risk management process to identify, measure and control material risks. (CP 13) (A pilot study on risk-based supervision that is now under way, may establish the basis for the $\mathrm{CBU}$ providing guidance in these areas.)
Still under discussion.

A dialog is ongoing to determine how best to address this recommendation

\section{Partial progress.}

There are no procedures to pre-approve holdings in listed banks in excess of 5 percent. The draft banking law extends the principle of pre-approval to non-listed banks.

\section{Informal progress only.}

No guidelines or circulars have been issued to address market risk in this context or require banks to have a comprehensive risk management process. However the CBU is in the third year of its risk-based supervision, in which they examine a bank's credit risk, operational risk, and market risk and how the bank implements policies to address them. 


\section{Status}

The CBU has assigned staff to look at drafting such circulars. They are expected to be distributed in the context of the implementation of Basle II.

Awaiting implementation of Basle II.

(4) Off-balance sheet items and inter-bank exposures to U.A.E. banks with maturities of less than 12 months should be included in the definition of large exposures. (CP 9)
(5) Members of a bank's staff who report suspicious transactions in good faith to the compliance officer of the CBU should be protected from being held liable (protection is included in the draft Banking Law). (CP 15)

\section{Securities}

(1) Work to eliminate the current state of market confusion which exists as a result of the Authority's delay in fully commencing operations.

(2) Rationalize the regulatory responsibilities of the ESCA, the CBU, the MOEP, and the securities markets as soon as possible, and effectively communicate the results to the markets.

\section{Completed}

ESCA is fully operational

\section{Groundwork has been laid.}

There is an expectation that ESCA will gradually undertake more responsibilities, but this shift cannot take place until the ESCA builds up its staff and capacity, which is an ongoing process. There has been discussion of creating a supervisory authority that would cover all types of securities regulation, but no action has been taken.

Under the law the ESCA has supervisory responsibility for brokerage houses, listed companies, and the two stock exchanges. It should also have responsibility for investment 
Status

(3) The ESCA should expeditiously commence its staffing exercise (the adequacy of qualified staff will greatly enhance the perception of market integrity).
(4) The two securities exchanges (Abu Dhabi and Dubai) should establish an electronic trading/clearing linkage as required under the law as soon as possible (this will contribute to both market efficiency and integrity).

(5) Significant effort should be expended to develop the corporate debt market and increase the participation of nonbank financial institutions such as pension funds, insurance companies, and mutual funds.

(6) Improvements should be made to the corporate governance environment including minority shareholder protections.

\section{Transparency}

(1) Transparency could be improved if all financial companies, mutual funds, IPOs, and nongovernment pension funds (which do not yet exist, but are envisioned). An ordinary broker may only deal with U.A.E. listed securities. A broker who wants also to deal with international securities has to be licensed by the Central Bank.

\section{Good and ongoing progress.}

Increases in staffing and training have been ongoing. Last year the number of staff increased by 50 percent. Training is provided locally, in the GCC region, and outside the region. In March MOUs were signed with Australia and Malaysia to exchange expertise.

\section{Completed}

There is an electronic trading linkage. There is no clearing linkage, but according to the authorities this is not required by the law. Companies are not cross listed on the exchanges. There are plans to completely merge the two exchanges. Both exchanges now settle on a $\mathrm{T}+2$ basis.

\section{Progress is underway.}

The ESCA plans shortly to issue a set of rules on the listing of bonds. A committee that includes all banks in the region has been established to develop bond markets in the region. The program is due to be completed within two years. There are currently two bonds listed on the DFM, Emirates Airlines, and the Government of Dubai.

\section{Progress is underway.}

A new set of rules on corporate governance is expected to be presented to the board of ESCA in April 2005. These rules will cover minority shareholder protections and insider trading. The new company law will also address governance issues.

Good progress. 


\section{Recommendation}

sector regulators and supervisors were more active in seeking stakeholders', including the private sector, inputs when they are contemplating changes in laws, regulations, technical requirements, policies, or otherwise.

\section{Legal reforms}

(1) Enact the proposed amendments to the companies legislation and make provision for improved minority shareholder rights, better corporate governance provisions and simplified company formation procedures. Improve operation of and accessibility to the Company Register.

(2) Improve registration procedures for movable property and create mechanisms for the registration of non-possessory pledges.

(3) Simplify the law relating to the ownership, transfer, and charging of real estate. Improve operation of the Land Registry and make it freely and fully accessible to the public.

(4) Enact the proposed amendments to the Banking Law, including the proposed anti money laundering provisions.

(5) Consider introducing an accelerated and simplified procedure for the handling of small value claims, e.g., claims under AED 50,000.

\section{Status}

All banks reported that they have good, continual communication with the CBU. Whenever changes in laws, regulations, technical requirements, or policies are contemplated their input is sought.

\section{Progress is underway.}

The authorities are currently drafting a new banking law and a new company law, both of which address corporate governance and minority shareholder rights.

\section{Good and ongoing progress.}

Registration procedures for many types of movable property have been improved. No information was provided on non-possessory pledges.

\section{Good and ongoing progress.}

Foreigners are now allowed to own land in Dubai and there are plans to allow this in all the Emirates. The Land Registry is freely available and fully accessible to the public.

\section{Good and ongoing progress.}

Several key laws have been passed, including Federal law \#4 of 2002 on anti-money laundering, Federal Law \#1 of 2004 which addresses combating the financing of terrorism, and Federal Law \#8 of 2004 which addresses AML/CFT in the financial free zone. Work continues on the new banking law, which has not yet been enacted.

No progress. 


\section{Recommendation}

\section{Insurance}

(1) Increasing the staff of the Insurance Division of MOEP to include more individuals who possess the skills necessary to carry out off-site analyses and on-site inspections. In addition, an appropriate official should be appointed as the U.A.E. Insurance Commissioner.

(2) Carrying out a full review of the insurance law and regulations with a view to bringing it up to current best practice, while allowing for the unique U.A.E. context. In the interim the proposed amendments to the insurance law should probably be held back. In particular a formal study of the capital requirements and investment risks for foreign branches is highly desirable.

(3) Reviewing the constraints inhibiting industry rationalization, with a view to making it more desirable for domestic companies, and easier for foreign branches to merge. In addition, where insurers are engaged in regional rather than local market activities there may be grounds for easing the rules on work visas and other requirements for non-nationals, although this would have to be tightly monitored.

(4) Developing a deeper and more liquid market for local property and securities by allowing some portfolio investment in key sectors by foreign insurers operating in the domestic market. This would encourage further development of local currency denominated investment and savings products, including Takaful. To ensure local participation in a growing life insurance industry joint ventures could be allowed (or required), for foreign involvement in local markets.

\section{Status}

Good and ongoing progress.

There is an ongoing process of hiring and training new staff. Recently seven new staff have been hired, bringing the total staff to 17 .

The creation of an independent authority for the supervision of insurance - which it was hoped would be completed by end-2004-is stillenvisioned. Once a new Authority is in place the relevant staff of the MOEP would be transferred to it.

\section{Partial and ongoing progress.}

No comprehensive study of the insurance law and regulations has taken place. However, gradual improvements have been ongoing. Two Ministerial decrees have been issued in recent years; one to improve transparency, and another to allow foreign entry into the insurance market. Amendments to the law in order to bring it into line with international standards are still envisioned.

Progress is unclear.

No specific legislation has been enacted. Review of constraints to rationalization or work visas has taken place only at a low level.

\section{Limited progress.}

There has been no specific progress on legislation. Publicly traded companies have gradually been allowing more foreign investment, though this is at their initiative. The upcoming free trade agreement with the United States and compliance with the WTO will require greater openness. 


\section{Recommendation}

\section{Payment system}

(1) The CBU should review its procedures for providing overdrafts and implement a system whereby the $\mathrm{CBU}$ only lends to banks against proper collateral. Publication of its overdraft procedures could also be considered.

(2) To prepare for increases in transaction volume and reduce reliance on manual procedures, the CBU should consider greater automation and computerization of the existing systems. In the interim, it could also consider limiting the value of different types of transfers - a minimum amount for a Telex Transfer and a maximum amount for a check.

(3) In the medium term, a move to a more advanced automatic system that would give the payment system both increased capacity and greater protection from operational risks. This might include moving from a $\mathrm{T}+1$ system for check settlement to same day settlement. Consideration should also be given to the risks involved with the introduction of the new real time gross settlement system that would replace the Telex Testkey System.

\section{Status}

\section{Partial progress.}

Lending is still made without requiring proper collateral, but the amount of the loan cannot exceed reserves on deposit with the $\mathrm{CBU}$, so the loan can be recovered by seizing required reserves. Such loans are for a maximum of six days and a penalty interest of five percent over the three-month interbank rate is applied.

These rules for overdrafts are publicly disclosed in a circular on the internet. The amounts of the overdrafts are not publicly disclosed.

\section{Completed.}

Automation and computerization have moved forward at a fast pace. Telexes are no longer used for any transfers. All transfers are made electronically and there is no need for any limits on different types of transfers.

\section{Good progress.}

Automation and computerization have been expanded. Telexes are no longer used for any transfers. Settlement system is still $\mathrm{T}+1$, but this will change when the image-based check clearing system is introduced 2005. 


\section{Statement by A. Shakour Shaalan, Executive Director for the United Arab Emirates July 1, 2005}

1. At the outset, we wish to express on behalf of the authorities our thanks to the staff for a constructive consultation process and for the well-balanced advice reflected in the rigorous set of reports before us. The authorities are in broad agreement with the thrust of the analysis and policy recommendations contained in the staff report.

\section{Recent Economic Developments}

2. The U.A.E. economy continued to perform strongly in 2004, underpinned by favorable oil market developments and a commitment to an outward-oriented and businessfriendly strategy. Although hydrocarbon revenues continue to play a dominant role in the economy, the authorities have firmly pursued an aggressive strategy to optimally utilize oil resources to intensify economic diversification and strengthen private sector activity in the non-oil sector. The dividends of this strategy are reflected in a robust economic growth, with non-oil growth remaining strong at 10 percent supported by the boom in the manufacturing, services and construction sectors, as well as increased non-oil exports and a healthy surplus on the current account of 12 percent of GDP. With a streamlined regulatory environment, buttressed by liberal employment policies and an advanced infrastructure, the U.A.E. emerged as one of the most competitive economies at the regional and, to a large extent, global levels. Bolstered by strong economic fundamentals, investor confidence was reflected in a boost in FDI inflows and a surge in equity markets. Economic activity further accelerated, as the economy generated an average of 177,000 jobs per year (almost ten times the annual increment to its national labor force), at a time when other economies were shedding them. Inflation edged up to 4.6 percent in tandem with the surge in economic activity.

3. The medium-term outlook for the economy is promising. Given the momentum in private sector activity and the favorable outlook for oil prices, the overall fiscal position remains resilient to shocks in oil prices as low as $\$ 23$ per barrel. Looking ahead, to reinforce the role of the U.A.E. in stabilizing global prices and supply of oil, the authorities are now embarking on huge investment projects with the aim of increasing production capacity to $3.5 \mathrm{mbd}$ by 2006 and to $4.0 \mathrm{mbd}$ in the longer term. Concurrently, the authorities have taken initiatives to tap into their vast resources of natural gas to reduce the reliance of the non-oil sector on changes in oil. The expectation is for natural gas production to fulfill the domestic demand for energy, especially in manufacturing, and to release more oil for exports.

\section{Fiscal Policy}

4. Guided by conservative assumptions about oil prices, fiscal policy in the U.A.E. is crafted to maintain fiscal sustainability over the medium term while implicitly ensuring intergenerational equity. Saving for future generations is essentially achieved through the large accumulation of foreign assets from surpluses on oil revenues by the government of 
Abu Dhabi. With higher oil revenues and a prudent expenditure policy, the consolidated fiscal position strengthened considerably, registering a surplus of over 18 percent of GDP, and the non-hydrocarbon deficit continued to narrow.

5. To consolidate the fiscal gains from oil revenues and further stimulate expansion of the non-hydrocarbon sector, the authorities are pursuing measures to enhance fiscal performance on two fronts: improving the budget structure and strengthening fiscal coordination among the Emirates. Regarding the budget structure, public expenditure management has been improved at the Federal level with the introduction of performancebased budgeting. In Abu Dhabi, reforms have been initiated to enhance the composition and quality of current spending. Agricultural and utility subsidies continue to decline, and one power plant has been privatized as part of the broader divestiture plan of the water and power sectors by 2006. Measures to rationalize the wage bill were also taken, notably through scaling back civil service employment and outsourcing certain services to the private sector. The authorities are cognizant of the concerns expressed by staff regarding the recent wage increase and its implications on domestic demand and employment. However, given the structural shift in oil prices and the limited fiscal impact of this measure, the authorities deemed it opportune to transfer part of the windfall to the population. In the period ahead, the authorities will remain vigilant to tighten financial policies should inflationary pressures emerge and continue with their active labor market policies to improve employability of their nationals. On the revenue side, measures to expand the revenue base are pursued. Specifically, deliberations are now underway to introduce a value-added tax (VAT), with the potential of eventual harmonization at the GCC level. The authorities have requested the Fund's technical assistance in this regard.

6. Given the current legal set up which grants considerable autonomy to the individual Emirates, the authorities are keenly aware of the importance of stronger coordination and harmonization of fiscal accounting among the Emirates, especially in the run-up to the GCC union. To this end, a new economic planning committee has been formed at the Federal level, with the objective of establishing a framework to guide and coordinate economic policy and statistics. This framework is expected to improve fiscal policy assessment and ensure consistency of policies at the Emirate level with the overall macroeconomic objectives.

\section{Monetary Policy and the External Sector}

7. Supported by a strengthened foreign asset position and sound financial policies, the pegged exchange rate system continues to serve the U.A.E. economy well. The cumulative appreciation since 1990, while partly mitigated by the recent real depreciation, does not appear to have affected overall competitiveness of the economy.

8. With the capital account being fully convertible, monetary policy relies on a prudent credit stance to smooth out domestic liquidity and support the peg. In view of the rapid growth in private sector credit and the emerging inflationary pressures, the Central Bank of U.A.E. (CBU) stands ready to tighten credit conditions if needed through an increase in the reserve requirements on demand deposits. The CBU further intends to extend the maturity of 
the certificates of deposits (CDs) issued, with the objective of expanding its range of instruments in managing liquidity and developing a CD-based repo market.

9. Recognizing the important role of trade openness and economic integration in catalyzing the diversification process, the authorities have intensified their efforts towards regional and global integration. At the regional level, deliberations are ongoing among GCC member countries on convergence criteria in the run-up to the monetary union. Specifically, five convergence criteria were discussed by the governors of the respective monetary authorities, including targets on inflation rates, short-term interest rates, foreign exchange reserves, as well as fiscal deficit and public debt ratios. In pursuing liberalization beyond the regional context, the authorities remain mindful of the principles of the GCC customs union. A Trade and Investment Framework Agreement (TIFA) with the U.S. was recently signed, boding well for the country's efforts to further strengthen its global relations.

\section{Financial Sector Issues}

10. The financial sector in the U.A.E. remains sound and its role as a regional hub continues to evolve. The banking sector is strong, well-capitalized and highly profitable, with prudential and oversight regulations being continuously strengthened. Despite a rapid growth in private sector credit, sound lending practices have effectively limited the exposure of the banking sector to the real estate boom. With limits set on the property value amenable to bank financing, total lending to real estate activities remained confined to less than five percent of total lending portfolio. The CBU has also intensified its efforts to reinforce existing regulations regarding the financing of IPOs, to safeguard the banking sector from excessive exposure to asset market risk.

11. Increased investor confidence, on the back of strong fundamentals, contributed to a boost in equity markets and a surge in asset prices, which appears to be a common phenomenon among emerging markets. The composite index of the Abu Dhabi and Dubai securities markets registered the highest growth among the GCC markets and market capitalization almost doubled. Furthermore, the regulatory and supervisory structures of the securities markets continue to be strengthened. To this end, the Emirate Securities and Commodities Authorities (ESCA) has been activated and its operations are being supported through increased employment and training of its staff. Transparency of the system has also been enhanced through several measures, including the establishment of a clear and detailed set of requirements for listing and disclosure. The authorities concur with staff on the importance of establishing a consolidated supervisory framework for the capital markets and the non-bank financial intermediaries. Fund assistance in the form of a Report on Standards and Codes (ROSC) has been requested to help lay the groundwork in this regard.

12. Progress has also been achieved in tightening regulations against money laundering and in strengthening the regulatory capability of the Dubai International Financial Center (DIFC). Two new laws were promulgated in 2004 addressing the financing of terrorism and AML/FATF issues in the free zones. With Dubai vying to become a major regional financial hub, the authorities have promptly established the regulatory framework for the DIFC in line with international best practice, in order to support the growing number of licensed financial 
institutions. Given the specific structure and arrangements governing its activities, the authorities have agreed to a review of the DIFC's operations by the Fund within year-end.

\section{Structural Policies}

13. The authorities' development strategy has focused on strengthening the investment competitiveness of the economy while according a prominent role to the private sector in leading growth in non-hydrocarbon activities. An investor-friendly environment was fostered through an efficient and modern infrastructure, a streamlined regulatory climate in production and employment, and a favorable attitude towards foreign ownership. These factors have reinforced the 'efficiency premium' of the U.A.E. economy, rendering it an attractive destination for FDI and a regional hub for a large number of international companies that cater to neighboring markets.

14. To intensify competitiveness and strengthen the investment climate, the authorities are advancing on several initiatives. An amended Commercial Company Law that extends foreign ownership beyond the current limit of 49 percent is currently being considered by the cabinet for approval. Additionally, and in line with staff recommendation, the authorities are considering a new FDI legislation that would ensure consistency of regulations across the Federation while allowing flexibility in economic policy at the Emirate level. Moreover, the Dubai International Arbitration Center (DIAC) has been established to improve settlement of business disputes and address weaknesses in investor protection and contract enforcement. Finally, to improve system disclosure, the Dubai Chamber of Commerce and Investment (CCI) is in the process of establishing a credit rating and reporting agency, with international affiliation and federation-wide jurisdiction.

15. The authorities are cognizant of the importance of generating productive employment opportunities for the growing national labor force. Their strategy has focused on measures to enhance the employability of nationals in the private sector without compromising the overall competitiveness of the economy. To this end, and in addition to various initiatives to promote entrepreneurship at the Emirate level, a national training agency has been established to better equip nationals for private sector employment. Furthermore, as part of the authorities' longer-term plans to improve the incentive structure and reduce the wedge between public and private sector wages and benefits, a pension scheme for nationals in both the public and private sectors has been adopted.

\section{Statistical Issues}

16. The authorities are aware of the importance — and urgency — of upgrading the economic and statistical database. Several measures to improve the institutional statistical framework governing the flow of information among the Emirates were initiated to this end. In addition to enhancing the role of the inter-ministerial Statistical Committee, the authorities have expressed interest in participating in General Data Dissemination System (GDDS) and have identified a coordinator at the Ministry of Planning and Economy. They are now preparing for the 2005 population census, which is expected to lay the statistical foundation 
for the implementation of several sectoral surveys in the future, including household budget surveys and business establishment surveys.

\section{Conclusion}

17. The authorities are thankful to the Fund for the provision of valuable technical assistance. In the period ahead, they will remain vigilant to deal with any domestic price pressures that may emerge, and focus their efforts on confronting the challenges that may arise in the process of meeting the GCC convergence criteria. 


\section{INTERNATIONAL MONETARY FUND}

\section{Public Information Notice}

\section{IMF Executive Board Concludes 2005 Article IV Consultation with the United Arab Emirates}

On July 1, 2005, the Executive Board of the International Monetary Fund (IMF) concluded the Article IV consultation with the United Arab Emirates. ${ }^{1}$

\section{Background}

An outward-oriented development strategy, a good record in macroeconomic management, and a business friendly environment have resulted in impressive economic growth in the U.A.E. over the years. Economic diversification has advanced rapidly, supported by an increasing role of the private sector, which has laid the foundation for further economic and social progress in the period ahead.

Reflecting sharply higher oil prices and increased oil production, strong investor confidence, and a significant increase in foreign direct investment (FDI), economic growth in the U.A.E. is estimated to have been very strong in 2004 . Preliminary data for 2004 indicate that the real nonhydrocarbon GDP grew at 10 percent, while hydrocarbon production rose 3 percent. Growth was broad based with most sub-sectors growing at historically high rates, with manufacturing leading the way, followed by services and construction. The depreciation of the U.A.E. dirham (AED) in real effective terms and strong economic growth in the U.A.E.'s export markets helped drive faster growth in manufactured exports. Both the external current account and consolidated fiscal balances are estimated to have recorded large surpluses in 2004 of 12 percent and 18.3 percent of GDP, respectively. The non-hydrocarbon deficit (excluding investment income) narrowed by about 5 percentage points of non-hydrocarbon GDP, to about 27.5 percent. Asset prices in the real estate and the stock markets have soared, aided by stronger economic

\footnotetext{
${ }^{1}$ Under Article IV of the IMF's Articles of Agreement, the IMF holds bilateral discussions with members, usually every year. A staff team visits the country, collects economic and financial information, and discusses with officials the country's economic developments and policies. On return to headquarters, the staff prepares a report, which forms the basis for discussion by the Executive Board. At the conclusion of the discussion, the Managing Director, as Chairman of the Board, summarizes the views of Executive Directors, and this summary is transmitted to the country's authorities.
} 
fundamentals and investor optimism. The composite equity market index rose by 88 percent in 2004. Net FDI is estimated to have reached US $\$ 9$ billion. The broad money stock rose by 23 percent, mainly on account of an increase in private sector credit.

The banking sector in the U.A.E remains strong, bolstered by effective supervision. Overall, the capital-assets ratio (CAR) declined slightly to just under 17 percent, as banks increased their lending activities, but remains well above prudential norms for all banks. At end-2004, while the official ratio of non-performing loans (NPL) to total loans remained somewhat high at 12.5 percent, provisions were considerable, bringing the net NPL ratio below 4 percent. Banks' exposure to the booming real estate sector has so far been limited. Information on the non-bank financial sector exposure to the real estate sector is not available. The U.A.E. authorities, including the Emirate and Securities and Commodities Authority (ESCA) have undertaken steps to continue to strengthen supervision of securities and non-bank financial institutions. Major steps have been taken to put in place a strong legal framework to prevent money laundering and financing of terrorist activities. Two laws were passed in 2004, one on dealing with financing of terrorism and the other addressing AML/CFT issues in the financial free zones. The Dubai International Financial Center (DIFC) began operations in September 2004. Considerable progress has been made with respect to the regulatory framework governing the DIFC, and an extensive set of laws has been established based on best international practices.

The pace of liberalization gained momentum, in particular in Dubai, and to a lesser extent in the other Emirates. Dubai's policy of extending foreign ownership of land and properties for real estate developments have resulted in a construction boom and a significant increase in FDI in this sector. Sharjah has also established a number of industrial free zones while the privatization of Abu Dhabi's utilities sector is proceeding as planned with one power plant being sold to private investors. Consideration is being given in Abu Dhabi to follow Dubai's example of relaxing government control over the real estate market. The Federal government continues to play an important role in the federation, taking the lead in public administration reforms by implementing a range of reforms including performance-based budgeting and setting up a modern treasury system.

The U.A.E.'s general policy has been to avoid imposing wide-ranging employment quotas for nationals as it recognizes the significance of expatriate labor's contribution to growth and to maintaining the competitiveness of the economy. However, given the rising unemployment among nationals, a string of new measures have been implemented in recent years which include raising the cost associated with hiring expatriate workers. The authorities are also taking measures to create employment opportunities for the U.A.E. nationals in the private sector. These measures include programs for training and job placement to match the needs of the private sector, entrepreneurship programs that provide funds at low rates to nationals for them to start their own businesses, and enactment of a pension plan for nationals working in the private sector in a plan equivalent to that which applies to the public sector.

\section{Executive Board Assessment}

Executive Directors agreed with the thrust of the staff appraisal. They commended the authorities of the U.A.E. for pursuing an outward-oriented development strategy and prudent macroeconomic policies, which have led to impressive economic growth, rapid development of the non-oil economy, and a sizable accumulation of foreign assets. They welcomed the 
continued progress in diversifying the economy and the implementation of structural reforms, which have enhanced the economy's resilience to external shocks.

Directors agreed that the medium-term outlook remains favorable and that the U.A.E. is in a good position to consolidate the recent gains from the high oil prices. They underscored, however, that soaring assets prices and emerging inflationary pressures warrant close monitoring. The sustainability of the U.A.E.'s growth prospects hinges on continued implementation of structural reforms and maintaining financial stability. Directors called on the authorities to promote private investment by lifting remaining impediments to foreign investments outside the free zones, and enhance the long-run employability of the national labor force through training and education.

Directors welcomed the authorities' prudent fiscal stance, as reflected in the narrowing of the non-hydrocarbon fiscal deficit and projected improvement in the overall fiscal balance. At the same time, they pointed to the need for greater fiscal policy coordination between the individual Emirates and the Federal government, standardized accounting systems, and an improved flow of data between the levels of government. They considered that the structure of the budget should be further strengthened by containing government employment and basing the civil service rewards system on productivity. Subsidies on water and electricity should also be phased out, and replaced by targeted payments to nationals below a certain income level. Directors welcomed the continued reduction in agricultural subsidies in the Emirate of Abu Dhabi.

Directors recommended that the revenue base be broadened to reduce reliance on oil and gas revenues, including by introducing a local property tax and a value-added tax, the latter in coordination with other members of the Gulf Cooperation Council. They supported the authorities' request for technical assistance from the Fund for the introduction of a VAT. Directors commented that efforts should also be made to strengthen the institutional capacity of tax administration.

Directors considered that the pegged exchange rate arrangement continues to be supported by strong economic fundamentals and sound financial policies, and provides an anchor for price stability and market confidence. They welcomed the authorities' open-mindedness as to the choice of exchange rate regime under the planned GCC monetary union, but cautioned that more flexible exchange rate regimes require greater institutional development of the foreign exchange markets, and well-defined risk management and intervention policies. They therefore recommended that the authorities formulate strategies in these areas at an early stage.

Directors considered that monetary policy remains appropriately geared to containing inflation. While recent increases in asset prices are attributable in part to strong economic fundamentals, the authorities were nevertheless urged to closely monitor equity and real estate markets and to tighten financial conditions if warranted. The authorities could consider higher provisioning rates for credits carrying greater-than-average risks, increasing the minimum amount of equity needed for approval of real estate and margin trading loans, and tightening collateral requirements.

Directors stressed that a system for collecting information on non-bank financial sector exposure to the real state market is needed.

Directors agreed that the financial sector in the U.A.E. remains sound and its role as a regional 
hub continues to evolve. They commended the authorities for the progress achieved in improving financial sector supervision. At the same time, they highlighted the need for rationalization and consolidation of regulatory oversight of the capital markets and nonbank financial intermediaries. Effective coordination between the central bank and the Emirate Security and Commodity Authority is needed to ensure that a comprehensive supervisory framework is in place for the entire financial sector. Directors supported efforts to develop a regulatory framework for the Dubai International Financial Center, and welcomed the authorities' agreement to have the Fund assess the Center's structure and operations by year-end. Directors commended the authorities for the work on a legal framework to prevent money laundering and the financing of terrorism.

Directors encouraged the authorities to broaden the scope of the investment regime outside the free zones and enhance its transparency. In this vein, they welcomed the authorities' effort in pursuing new foreign direct investment legislation and an amendment to the Commercial Company law, which would further the development of an unambiguous legal framework for the private sector.

Directors commended the U.A.E.'s open-border foreign labor policy, which has enabled the private sector to recruit expatriate workers at internationally competitive wages and contributed to economic growth. They welcomed the measures to increase employment of nationals in the private sector, which should continue to rely on raising the skills of nationals through better education and training programs, rather than on mandatory measures such as quotas. Labor market reforms should aim at increasing flexibility in hiring and firing, and equalizing benefits for nationals in the private and public sectors.

Directors welcomed the measures to improve the institutional statistics framework, including the efforts of the Interministerial Statistical Committee and the authorities' intention to participate in the General Data Dissemination System. Nevertheless, the statistical database and procedures need to be strengthened to enable effective monitoring of the economy. The compilation of statistics on consolidated government activities needs to be improved, and structural weaknesses with respect to data quality, coverage, periodicity, timeliness, and inter-sectoral consistency need to be addressed. Better coordination between the Federal and Emirates authorities, the commitment of adequate resources, and further staff training will be needed to make progress in this area.

It is expected that the next Article IV consultation with the U.A.E. will be held on the standard 12-month cycle.

Public Information Notices (PINs) form part of the IMF's efforts to promote transparency of the IMF's views and analysis of economic developments and policies. With the consent of the country (or countries) concerned, PINs are issued after Executive Board discussions of Article IV consultations with member countries, of its surveillance of developments at the regional level, of post-program monitoring, and of ex post assessments of member countries with longer-term program engagements. PINs are also issued after Executive Board discussions of general policy matters, unless otherwise decided by the Executive Board in a particular case. 
United Arab Emirates: Selected Economic Indicators, 2000-04 1/

\begin{tabular}{|c|c|c|c|c|c|}
\hline & 2000 & 2001 & 2002 & 2003 & $\frac{\text { Prel. }}{2004}$ \\
\hline & \multicolumn{5}{|c|}{ (Annual change in percent) } \\
\hline \multicolumn{6}{|l|}{ National accounts and prices } \\
\hline Real GDP (at factor cost) & 12.4 & 1.7 & 2.6 & 11.6 & 7.8 \\
\hline Hydrocarbon 2/ & 13.1 & 0.0 & -7.6 & 13.6 & 2.9 \\
\hline Nonhydrocarbon 3/ & 12.0 & 2.5 & 7.7 & 10.8 & 9.9 \\
\hline Consumer price index & 1.4 & 2.8 & 2.9 & 3.1 & 4.6 \\
\hline Investment (in percent of GDP) & 23.2 & 24.7 & 24.0 & 23.4 & 22.1 \\
\hline \multicolumn{6}{|c|}{ (In percent of GDP; unless otherwise indicated) } \\
\hline \multicolumn{6}{|l|}{ Financial variables } \\
\hline Total revenue & 44.3 & 37.1 & 41.8 & 41.1 & 42.7 \\
\hline Hydrocarbon & 32.8 & 26.6 & 32.6 & 32.8 & 33.0 \\
\hline Nonhydrocarbon 4/ & 11.5 & 10.5 & 9.1 & 8.4 & 9.7 \\
\hline Total expenditure & 31.8 & 37.4 & 31.5 & 28.2 & 24.4 \\
\hline Of which: Current expenditure & 26.8 & 30.0 & 26.3 & 22.8 & 20.8 \\
\hline Consolidated fiscal balance (deficit -) 5/ & 12.4 & -0.4 & 10.3 & 13.0 & 18.3 \\
\hline $\begin{array}{l}\text { Consolidated fiscal balance (excluding } \\
\text { investment income) }\end{array}$ & 6.6 & -4.9 & 7.1 & 9.9 & 14.7 \\
\hline Excluding hydrocarbon revenue $6 /$ & -26.2 & -31.5 & -25.5 & -22.8 & -18.3 \\
\hline Change in broad money supply (In percent) & 15.3 & 15.3 & 15.6 & 16.1 & 23.2 \\
\hline Change in private sector credit (In percent) & 8.7 & 8.8 & 11.3 & 13.5 & 24.7 \\
\hline \multicolumn{6}{|c|}{ (In billions of U.S. dollars; unless otherwise indicate) } \\
\hline \multicolumn{6}{|l|}{ External sector } \\
\hline Exports & 49.6 & 47.5 & 52.5 & 67.3 & 82.3 \\
\hline Of which: crude oil 2/ & 21.7 & 17.6 & 16.6 & 22.1 & 29.6 \\
\hline Imports, fob & -30.8 & -33.5 & -37.5 & -45.8 & -54.2 \\
\hline Current account balance 4/ & 12.2 & 6.5 & 3.8 & 7.7 & 12.3 \\
\hline In percent of GDP & 17.2 & 9.4 & 5.0 & 8.7 & 11.8 \\
\hline Central Bank reserves & 13.8 & 14.3 & 15.3 & 15.1 & 18.6 \\
\hline In months of imports of goods and services & 4.9 & 4.6 & 4.0 & 3.3 & 3.5 \\
\hline Total external debt $7 /$ & 18.2 & 19.4 & 16.7 & 16.5 & 15.8 \\
\hline In percent of GDP & 25.8 & 27.9 & 22.3 & 18.7 & 15.1 \\
\hline $\begin{array}{l}\text { Average real effective exchange rate (CPI } \\
\text { based; in percent) (appreciation }+ \text { ) 8/ }\end{array}$ & 5.9 & 6.5 & -0.5 & -7.8 & -5.1 \\
\hline
\end{tabular}

Sources: Data provided by the authorities; and IMF Staff estimates.

$1 /$ Based on official data as of March 2005.

2/ Includes condensates.

$3 /$ Includes refined products and liquid gas.

4/ Includes investment income on government foreign assets estimated by IMF staff.

5/ Includes the fiscal position of the Federal government and the three largest Emirates, and following internationally accepted methodology for government accounts, investment income from the government's financial wealth as part of revenue.

6/ The overall balance excluding investment income and hydrocarbon revenue.

7/ Includes central bank and commercial bank foreign liabilities, plus private nonbanks based on reporting BIS banks.

8/ IMF staff estimates. 